\title{
LATE PLEISTOCENE (EEMIAN) MOLLUSK AND SMALL MAMMAL FAUNA FROM MIKHAILOVKA-5 (KURSK OBLAST, CENTRAL RUSSIA)
}

\author{
ALEXANDER K. AGADJANIAN' ${ }^{1}$ PETER KONDRASHOV2,** \\ ${ }^{1}$ Paleontological Institute of the Russian Academy of Sciences, 123 Profsoyuznaya St., 117868 Moscow, Russia; \\ e-mail: aagadj@paleo.ru. \\ ${ }^{2}$ A. T. Still University, Kirksville College of Osteopathic Medicine, 800 W. Jefferson St., Kirksville, MO 63501 USA, \\ e-mail: pkondrashov@atsu.edu. \\ * corresponding author
}

Agadjanian, A. K., Kondrashov, P. (2019): Late Pleistocene (Eemian) mollusk and small mammal fauna from Mikhailovka-5 (Kursk oblast, Central Russia). - Fossil Imprint, 76(1): 17-39, Praha. ISSN 2533-4050 (print), ISSN 2533-4069 (on-line).

\begin{abstract}
The locality Mikhailovka-5 is situated in the northern part of the Mikhailovka quarry in the northwest of the Kursk Oblast in central Russia. A rich mollusk fauna was collected along with small mammal remains from this lacustrine deposit located between Likhvinian (= Holsteinian) fossil soils and Valdayian (= Weichselian) periglacial deposits. The small mammal fauna is diverse, and includes numerous rodents, e.g., such indicative taxa as Arvicola ex gr. sapidus and Microtus ex gr. agrestis, a significant number of Clethrionomys glareolus and various insectivores. This assemblage closely corresponds to other Mikulino (= Eemian) faunas from the Russian Plain. The mollusk fauna includes a large number of terrestrial species, some of which have currently a more southern and western distribution. Both the molluskan and mammal faunas from Mikhailovka-5 indicate temperate climatic conditions, as evidenced by the diversity of insectivores, particularly the moles. Abundant remains of rodents of the genera Clethrionomys, Apodemus, and Microtus (Terricola) and of mollusks such as Acme, Macrogastra, Ruthenica, Punctum, and Acanthinula indicate the presence of extensive woodlands of mixed or broadleaf type, which were typical for this latitude during the Eemian interglacial. The palaeontological data provided in this paper, confirm that Mikhailovka-5 belongs to the Mikulino interglacial, as previously suggested by pedological arguments.
\end{abstract}

Key words: Russia, Late Pleistocene, Mikulino, Eemian, mollusks, small mammals

Received: February 28, 2019 | Accepted: March 20, 2020 | Issued: November 9, 2020

\section{Introduction}

Gerhard Storch was a prominent palaeontologist and a good man. He was a well-rounded biologist, and his professional interest spanned from Eocene bats of Tanzania to Pleistocene voles of Central Europe. One of his greatest achievements was the study of the Messel Eocene fauna. He described some of the most interesting taxa from this unique locality, including the enigmatic 'xenarthran'-like Eurotamandua joresi, pangolin-like Eomanis, Pholidocercus, leptictids, and others. His work greatly enriched our understanding of zoogeography and evolutionary biology of various groups of mammals. Gerhard Storch was a distinguished representative of the classic school of morphologists, and his descriptions of fossil mammals are precise and complete. In addition to being an outstanding naturalist, he loved and deeply understood nature, which added a special touch to his reconstructions of extinct animals and the ecosystems they lived in. Such an approach to palaeontological research is extremely important: to see beyond the fossil remains and bring them back to living creatures that had existed several hundreds of thousands or even millions of years ago.

In our paper, we strove to achieve such an approach to the study of a very interesting mollusks and small mammal fauna from the Mikhailovka quarry. Precambrian, Paleozoic, Mesozoic, and late Cenozoic deposits have been exposed in this quarry, located in the central part of the Russian Plain. Pleistocene deposits have been exposed in an extension of more than $20 \mathrm{~km}$ and include both terrestrial deposits, represented by loesses and fossil soils, and aquatic deposits, formed within ancient valleys. The geological and pedological studies of these deposits allowed detailed reconstructions of the sediment deposition in this region. The molluskan and mammalian remains therein allow a comprehensive reconstruction of environmental conditions in the central part of the Russian Plain during major parts of the Pleistocene. The fauna of Mikhailovka-5 is of special focus and will be described and discussed in the present paper. 


\section{Materials, methods and locality}

\section{Material and methods}

Mammalian and molluskan fossils (both originated from the same samples) were obtained by screen-washing of sediment with a mesh size of $1 \mathrm{~mm}$, then dried and sorted. The material consists of nearly 5,000 identifiable specimens of mollusks and 500 specimens of small mammals (Tabs 1, 2). Dental morphology of the two most significant taxa in this fauna, Microtus (Terricola) ex gr. subterraneus and Arvicola ex gr. sapidus, was described in detail (see chapter "Two significant small mammal taxa from Mikhailovka-5") because the dental morphology of these species underwent rapid changes during the Late Pleistocene and Holocene. All specimens are housed at the Borissiak Paleontological Institute of the Russian Academy of Sciences in Moscow, Russia.

\section{The Mikhailovka quarry}

\section{Regional context}

Geological outcrops in the Kursk and Lipetzk Oblasts play an important role in the interpretation of major stages of evolution of molluskan and mammalian faunas of the Dnieper and Don basins during the Quaternary. This region is situated in the watershed area of the Central Russian Upland. It was not covered with glaciers during the Pleistocene and hence there are no moraine deposits. However, it contains extensive subaerial deposits from the Early, Middle, and

Table 1. Mollusk species from Mikhailovka-5.

\begin{tabular}{|c|c|c|}
\hline Taxon & $\begin{array}{c}\text { Number of } \\
\text { specimens }\end{array}$ & $\%$ \\
\hline Acme (Platyla) polita (Hartmann, 1840) & 211 & 4.3 \\
\hline Carychium minimum MüLLER, 1774 & 784 & 15.9 \\
\hline Carychium tridentatum (Risso, 1826) & 1,365 & 27.6 \\
\hline Succinea putris (LinNAEUs, 1758) & 4 & 0.1 \\
\hline Succinella oblonga (DRAPARNAUD, 1801) & 2 & 0.04 \\
\hline Vallonia (Vallonia) costata (MüLLER, 1774) & 453 & 9.2 \\
\hline Vallonia (Vallonia) pulchella (MüLLER, 1774) & 370 & 7.5 \\
\hline Acanthinula aculeata (MüLLER, 1774) & 14 & 0.3 \\
\hline Cochlicopa (Cochlicopa) lubrica (MüLLER, 1774) & 2 & 0.04 \\
\hline Vertigo (Isthmia) pygmaea (DRAPARNAUD, 1801) & 19 & 0.4 \\
\hline Vertigo (Vertigo) pusilla MüLLER, 1774 & 13 & 0.3 \\
\hline Vertigo (Vertigo) antivertigo (DRAPARNAUD, 1801) & 1 & 0.04 \\
\hline Vertigo (Vertigo) substriata (JEFFREYs, 1830) & 288 & 5.8 \\
\hline Vertilla angustior (JEFFREYs, 1830) & 1,248 & 25.2 \\
\hline Truncatellina cylindrica (FÉRUSSAC, 1807) & 4 & 0.1 \\
\hline Euconulus fulvus (MüLLER, 1774) & 7 & 0.1 \\
\hline Discus ruderatus ruderatus (STUDER, 1820) & 11 & 0.2 \\
\hline Punctum pygmaeum (DRAPARNAUD, 1801) & 117 & 2.4 \\
\hline Macrogastra plicatula (DRAPARNAUD, 1801) & 13 & 0.3 \\
\hline Ruthenica filograna (ROSSMÄSSLER, 1836) & 7 & 0.1 \\
\hline Planorbis planorbis (LinNAEUs, 1758) & 7 & 0.1 \\
\hline Lymnaea (Lymnaea) stagnalis (LinNAEUs, 1758) & 4 & 0.1 \\
\hline Total & 4,944 & 100 \\
\hline
\end{tabular}

Table 2. Mammal species from Mikhailovka-5.

\begin{tabular}{|c|c|c|}
\hline Taxon & $\begin{array}{l}\text { Number of } \\
\text { specimens }\end{array}$ & $\%$ \\
\hline Talpa ex gr. europaea LinNAEUs, 1758 & 16 & 3.2 \\
\hline Sorex cf. minutus LINNAEUs, 1758 & 1 & 0.2 \\
\hline Sorex ex gr. araneus LinNAEUs, 1758 & 19 & 3.9 \\
\hline Sorex sp. & 8 & 1.6 \\
\hline Ochotona cf. pusilla (PALLAs, 1769) & 5 & 1 \\
\hline Spermophilus ex gr. suslicus (GüLDENSTAEDT, 1770) & 18 & 3.7 \\
\hline Apodemus ex gr. sylvaticus (LinNAEus, 1758) & 6 & 1.2 \\
\hline Clethrionomys glareolus (SCHREBER, 1780) & 30 & 6.1 \\
\hline Eolagurus sp. & 1 & 0.2 \\
\hline Arvicola ex gr. sapidus (MiLLER, 1908) & 95 & 19.4 \\
\hline $\begin{array}{l}\text { Microtus (Terricola) ex gr. subterraneus } \\
\text { (SELYS-LONGCHAMPS, 1836) }\end{array}$ & 12 & 2.4 \\
\hline Microtus (Stenocranius) gregalis (PALLAS, 1779) & 2 & 0.4 \\
\hline Microtus arvalinus Hinton, 1923 & 8 & 1.6 \\
\hline Microtus ex gr. agrestis (LinNAEus, 1758) & 107 & 21.9 \\
\hline Microtus sp. & 132 & 27 \\
\hline Spalax ex gr. microphtalmus (GüLDENSTAEDT, 1770) & 29 & 5.9 \\
\hline Total & 489 & 100 \\
\hline
\end{tabular}

Late Pleistocene. As part of the Kursk Magnetic Anomaly, this part of the Central Russian Upland has been extensively excavated for iron ore mining, resulting in a vast system of quarries throughout the basins of the Svapa River to the Oskol River. The quarries cut through Mesozoic and Cenozoic deposits on both the watersheds and river basins. One of the largest quarries is the Mikhalovsky mining complex in the northwestern part of Kursk Oblast near the town of Zheleznogorsk on the right bank of the Svapa River (Text-fig. 1). The exposed sediments are more than $300 \mathrm{~m}$ thick, but mining takes place only on the southwestern slope of the watershed at layers 260-268 m above sea level.

\section{Geologic setting and included faunas}

The Pleistocene deposits exposed in the Mikhailovka quarry exceed $20 \mathrm{~km}$ in total. Their thickness reaches up to $35 \mathrm{~m}$. In the southern and western parts of the quarry, Quaternary sediments are mainly represented by loess and soil formations of the Middle and Late Pleistocene (Text-fig. 2). The underlying alluvial deposits reach a thickness of $3 \mathrm{~m}$. An ancient depression, which includes lacustrine and alluviallacustrine deposits, has been exposed in the northern part of the quarry. The fossil-bearing strata are mainly of aquatic origin. However, in the northwestern section, transitions from loesses and fossil soils to lacustrine deposits allow correlations between the terrestrial and aquatic deposits. Sections 50 and 59 are the most indicative outcrops and are described in more detail here.

Section 50, a fossil watershed, is located in the western part of the Mikhailovka quarry. The following layers are exposed from top to bottom (Text-fig. 3):

- Layer 1. Dark brown, loose, lumpy loam; black in the upper horizon, gets lighter toward the bottom, contains silica (modern soil). $0-1.0 \mathrm{~m}$. 


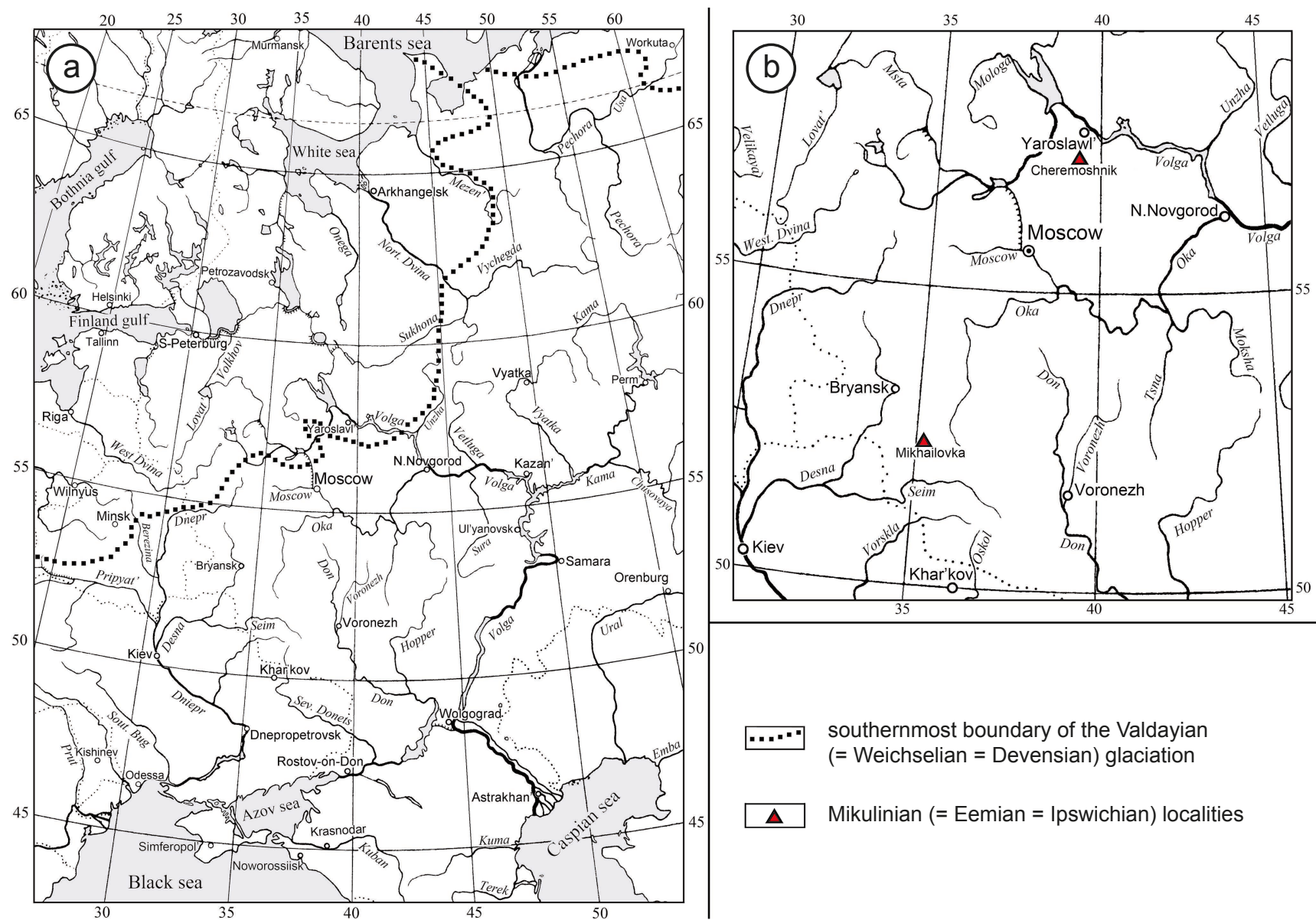

Text-fig. 1. Geographic setting of the locality Mikhailovka-5. a: map of the Russian Plain, b: map of the central part of the Russian Plain.

- Layer 2. Light brown, porous, dusty loam; slightly darkens toward the base ( $1^{\text {st }}$ fossil soil). $1.0-2.25 \mathrm{~m}$.

- Layer 3. Brown, dense loam with well-formed clumps and carbonate pseudomycelium, small spots of iron and manganese hydroxides; the middle part has silica $\left(2^{\text {nd }}\right.$ fossil soil). 2.25-3.4 m.

- Layer 4. Light, dusty, nearly white loam; light brown in the upper part, greenish in the lower. It becomes sandier in the lower part with more horizontal lamination. 3.4-15.1 m.

- Layer 5. Dark grey loam with a brown tint; contains black spots of manganese hydroxides and rusty spots of iron. The lower part contains a layer of loess-like sandy clay $\left(3^{\text {rd }}\right.$ fossil soil). 15.1-15.6 m.

- Layer 6. Dark brown, dense, lumpy loam; lighter in the lower part. Concretions of iron and manganese hydroxide occur throughout the layer. Lower boundary is irregular with prominent wedges cutting into the next layer ( $4^{\text {th }}$ fossil soil). $15.6-17.4 \mathrm{~m}$

- Layer 7. Black-brown, dense, lumpy loam; containing numerous iron and manganese hydroxide concretions. Lower part of the layer is lighter-coloured and has powdery structure ( $5^{\text {th }}$ fossil soil). 17.4-19.6 m.

- Layer 8. Brown, dense, grainy loam with a rusty tint; iron and manganese hydroxide concretions and spots and occasional molehills. Lower boundary is unclear $\left(6^{\text {th }}\right.$ fossil soil). 19.6-22.0 m.

- Layer 9. Grey, slightly sandy aleurites with a brown tint and horizontal lamination. It darkens, becomes denser and bluish toward the bottom. 22.0-25.5 m.
- Layer 10. Dense grey brown clay with numerous quartz granules. Lower boundary well defined. 25.5-27.52 m.

- Layer 11. Middle- to large-grain grey sand with a brownish tint; contains gravel and pebbles.

Most of the layer is horizontally laminated, and the bottom part is obliquely laminated. Among the larger fragments are carbonate concretions, phosphorites, sandstone pieces, and rarely mammalian bones (Mikhailovka-1). Lower boundary well expressed, wavy, slightly washed out. 27.52-31.0 m. Layer 11 overlies Cretaceous glauconitic sands.

The majority of the section in this part of the quarry is formed of loesses and fossil soils. The upper soil (layer 1) belongs to the Bryansk period, the second soil from top (layer 2) to the Mikulino interglacial, and soils in layers 3-6 are of Middle Pleistocene age (Glushankova 2008a). Alluvial deposits underlying the $6^{\text {th }}$ fossil soil are located at depths of 27.52-31 $\mathrm{m}$ and can be traced across the quarry for $10-15 \mathrm{~km}$ horizontally.

The basal horizon of layer 11, referred to as Mikhailovka-1, contains small mammal remains (of arvicolines, insectivores, lagomorphs, ground squirrels, and beavers), and dates to the Early Pleistocene (Agadjanian 2009). Most numerous and diverse among voles are species of the genera Mimomys and Villanyia (by several researchers representatives of the latter genus are referred to Borsodia), with Mimomys being most common and represented by presumably four species. The fauna contains also a few specimens of the archaic vole Allophaiomys pliocaenicus 


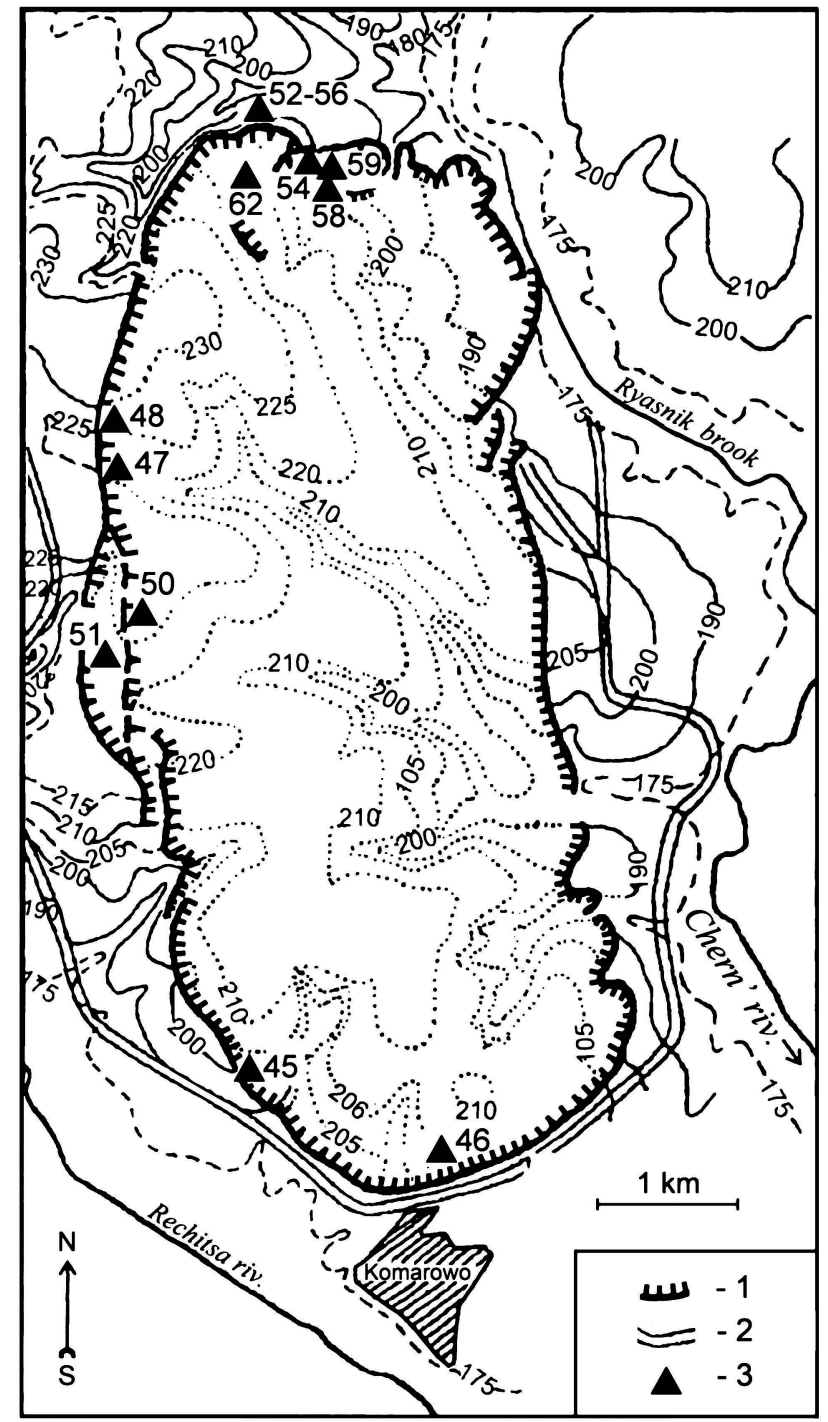

Text-fig. 2. Map of the Mikhailovka quarry. 1 - wall of the quarry, 2 - roads, 3 - position and number of sections.

with rootless molars, and a single molar of the red backed vole genus Clethrionomys.

The age of this fauna is implied from the diverse and abundant remains of Mimomys and the low numbers of Allophaiomys. Such assemblages are typical for most ancient faunas of the Taman faunal complex of the Early Pleistocene near the boundary between the Akchagyl and Apsheron stages at approximately 1.8 Ma (Agadjanian 2009). Similar faunas were described from the Tegelen Clay in the Netherlands (Freudenthal et al. 1976, Tesakov 1998). However, these faunas lack voles with rootless teeth, in contrast to the Mikhailovka-1 fauna.

Section 59 is an outcrop of Pleistocene deposits exposed in the northern part of the Mikhailovka quarry. It represents an ancient valley and its structure is different from that of section 50. Cretaceous sands underneath the Pleistocene deposits have been washed out, and Quaternary deposits rest directly on Jurassic clays. The section consists of the following layers from top to bottom:

- Layer 1. Dark brown, loose, lumpy loam; black in the upper part (modern soil). 0-0.6 m.
- Layer 2. Dark grey, porous, dusty loam with carbonate pseudomycelium. $0.6-1.5 \mathrm{~m}$.

- Layer 3. Light brown, loess-like loam. Lower boundary gradual. $1.5-2.2 \mathrm{~m}$.

- Layer 4. Dense aleuritic loam, grey with a brown tint. Lower boundary gradual. 2.2-2.5 m.

- Layer 5. Light brown, porous, grainy loam with a brown tint; black spots of manganese hydroxides and rusty spots of iron. Lower boundary gradual. $2.5-4.15 \mathrm{~m}$.

- Layer 6. Brown loam with a rusty tint and wellexpressed lumpy-grainy structure. $4.15-5.2 \mathrm{~m}$.

- Layer 7. Light brown mottled loam with dark-brown and light-grey traces of molehills. Lower boundary is well defined. $5.2-8.0 \mathrm{~m}$.

- Layer 8. Light grey loam with a brown tint, horizontally laminated. Lower part of the layer is formed by the washed up lacustrine marl. 8.0-8.5 m.

- Layer 9. Thin layer with plant organic material, washed up soil particles, mollusk shells and bones of small mammals and frogs (Mikhailovka-5). $8.35-8.5 \mathrm{~m}$.

- Layer 10. Light gray aleuritic loam with a green tint and black spots of manganese hydroxides. Weakly laminated horizontally. Gastropod shells are found throughout the layer; the lower horizon contains carbonate concretions. 8.5-9.7 m.

- Layer 11. Dense loam, weakly laminated horizontally. Light grey with a greenish tint in the upper part and grey with a brown tint in the lower part. Lower boundary gradual. 9.7-11.9 m.

- Layer 12. Dense, brown aleurites; weakly laminated horizontally. 11.9-12.6 m.

- Layer 13. Light brown, mottled loam with reddish spots and well expressed lumpy-grainy structure. The lower horizon is lighter, contains carbonate pseudomycelium and few molehills (Middle Pleistocene soil). 12.6-15.3 m.

- Layer 14. Dense, gray clay with rusty spots of iron, horizontally laminated. $15.3-18.6 \mathrm{~m}$.

- Layer 15. Dense, blue-green clay with rusty spots of iron and lenses of sand. There is a horizon of large carbonate concretions at 21-22 m. Horizontal and locally oblique lamination is well expressed. Remains of small mammal, mollusks, insects, and plants are found at the base of this layer (Mikhailovka-2). The basal horizon of the clays contains large grains of sand. Lower boundary is uneven but well expressed. This layer rests on black Jurassic clays. $18.6-24 \mathrm{~m}$.

The majority of Pleistocene sediments in section 59 are aquatic. It is possible to trace the two fossil soils transitioning into diluvial, lacustrine and alluvial deposits. Fossils were obtained from the basal horizon of layer 15 (Mikhailovka-2) and from aquatic deposits underlying the Mezin $($ Mikulinian = Eemian) fossil soil (Mikhailovka-5) . A few remains were obtained from the brown loam covering the blue-green lacustrine clays of layer 15 in nearby section 62 (Mikhailovka-3). Small mammal remains were also found in the alluvial deposits overlying the Mezin soil.

Mikhailovka-2 is stratigraphically the lowest and the oldest locality in this series.

Two hundred eighty small mammal fossils collected from the lacustrine clays of layer 15 (Mikhailovka-2) are 

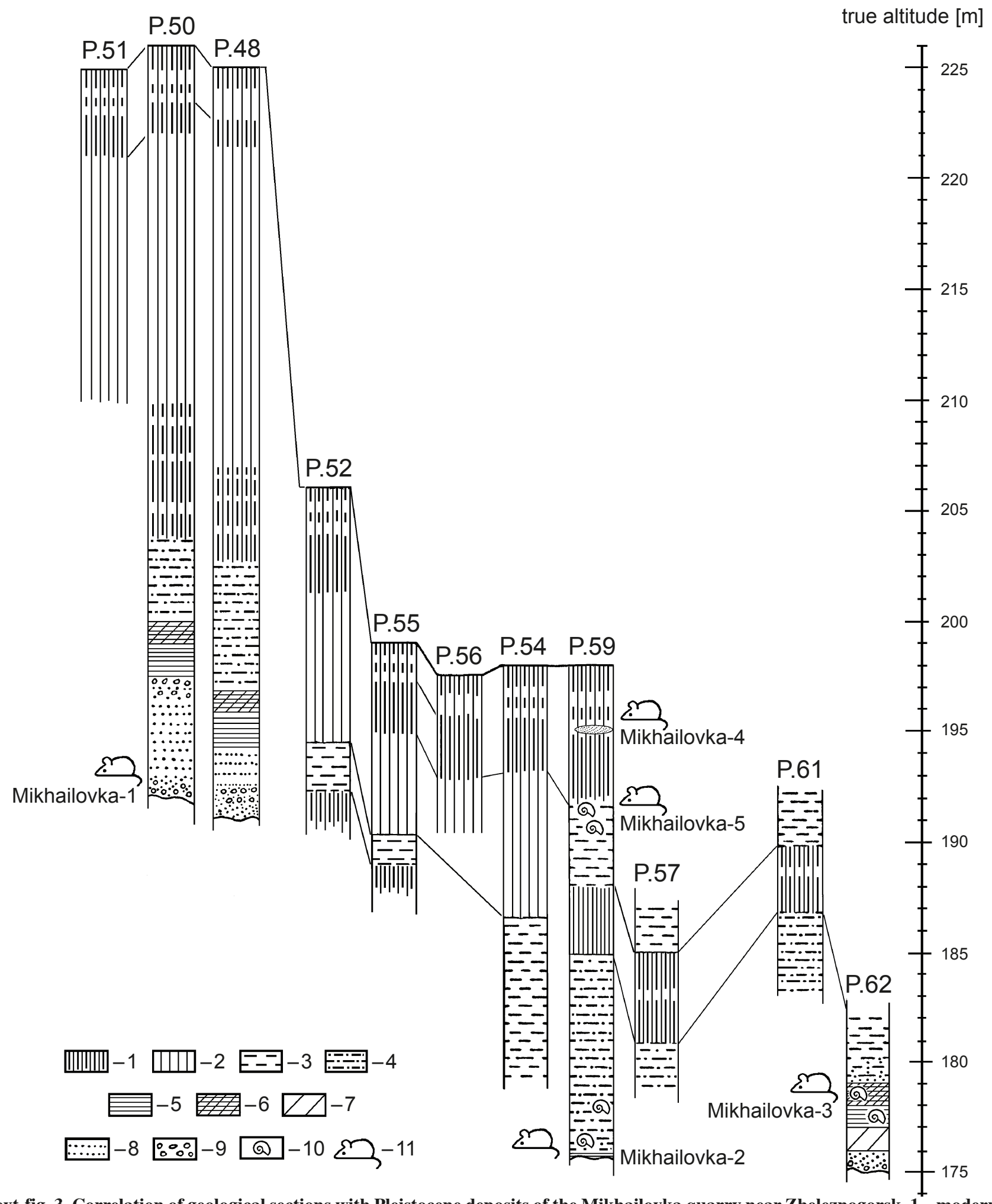

Text-fig. 3. Correlation of geological sections with Pleistocene deposits of the Mikhailovka quarry near Zheleznogorsk. 1 - modern and fossil soils, 2 - loess-like loam, 3 - sandy clay, 4 - aleurites, 5 - horizontally laminated clays, 6 - brown loams, 7 - blue clays and loams, 8 - sands, 9 - gravels, 10 - mollusk shells, 11 - small mammal remains.

well preserved and include jaw fragments and postcranial bones (Agadjanian 2009). Dominant species are the collared lemming Dicrostonyx simplicior okaensis Alexandrova, 1982 (45.5\%), and the narrow-headed vole Microtus (Stenocranius) gregalis (PALLAS, 1779) (11.4 \%). Another frequent species is the steppe lemming Lagurus transiens JÁNOSSY, 1962 (4.3\%). In small numbers occur pika (Ochotona sp.), ground squirrel (Spermophilus sp.), red- backed vole Clethrionomys ex gr. glareolus (SCHREBER, 1780), lemming (Lemmus), and pine vole (Microtus (Terricola) sp.) Ecologically, this fauna is unequivocally periglacial since most of its components are tundra (lemmings) or steppe (steppe lemmings and ground squirrels) species or species found in both zones (narrow-headed vole). The dominance of Dicrostonyx lemmings indicates open landscapes with shrubby tundra. Such conditions existed in the central part 
of the Russian Plain only during glaciation and indicate that the fauna of Mikhailovka-2 corresponds to a glacial epoch in Eastern Europe.

The age of Mikhailovka-2 is implied from the evolutionary level of its major components, the collared lemming, the steppe lemming, and the narrow-headed vole. Detailed analysis of the tooth morphology of Dicrostonyx simplicior indicate that the collared lemming from this site belongs to the most archaic representatives of this taxon (Agadjanian 2009). It is very similar to lemmings from the pre-Likhvinian (= pre-Holsteinian) deposits of the Chekalin section (Alexandrova 1982) that are dated to the Okian glaciation (= Mindel, Anglian, Elsterian). Thus, the fauna of Mikhailovka-2 belongs to MIS 12 of the Middle Pleistocene $(=$ Okian $=$ Mindelian $/$ Elsterian $=$ Anglian glacial $)$.

Another small mammal fauna was found in the northern part of the Mikhailovka quarry in section 62, a bone-bearing horizon overlying the blue-green lacustrine clays of layer 15 referred to as Mikhailovka-3 (Agadjanian 2009). The dominant elements of this fauna are grey voles Microtus and steppe pika; the red-backed vole is fairly common as well. The presence of Microtus (Stenocranius) gregalis, a ground squirrel, and a steppe pika indicates the presence of open landscapes. The presence of the gray vole morphologically close to Microtus hyperboreus VinOGRAdOv, 1933 indicates an environment similar to that of the modern forest tundra. Red-backed voles indicate the presence of broadleaf or coniferous forests. It is likely that the landscapes of the studied fauna resembled the modern northern part of the taiga zone with small patches of steppe-like habitats. Compared to the lemming fauna from the underlying bluegreen clays of layer 15 of section 59 (Mikhailovka-2), the climate at this locality was still fairly cold and dry but with a trend to more temperate conditions. Presumably, the fauna of Mikhailovka-3 represents a transitional stage between the Okian glaciation to the Likhvinian (= Holsteinian) interglacial (Agadjanian 2009).

The youngest small mammal fauna in the Mikhailovka quarry is Mikhailovka-4, which was found in its northern part and formed within an ancient valley (Agadjanian 2009). In this part of the section, the Middle Pleistocene deposits along with lacustrine deposits and overlying Mezin soils are lacking because they were washed out. The ancient valley was filled with re-deposited loess-like loams that transitioned toward the bottom into horizontally laminated lacustrine clays of $5 \mathrm{~m}$ thickness. In the lower part of the section, these clays overlie middle- to large-grain sands with small pebbles in the basal horizon (thickness $2 \mathrm{~m}$ ). The sands rest on black Jurassic clays with an uneven, washedout boundary. These lacustrine-alluvial clays and sands correlate with silts and loams of the upland part of the section that overlie the Mezin (Mikulinian = Eemian) fossil soils. These younger alluvial deposits are obliquely laminated in the basal part and contain glacial pebble fragments. This basal horizon contains mammal remains and is referred to as the Mikhailovka-4 (Agadjanian 2009). Several hundred bone fragments have been collected, 150 of which have been identified. The dominant species in this locality are the water vole (Arvicola cf. terrestris), narrow-headed vole (Microtus (Stenocranius) gregalis), steppe lemming (Lagurus lagurus), and red-backed vole (Clethrionomys glareolus).

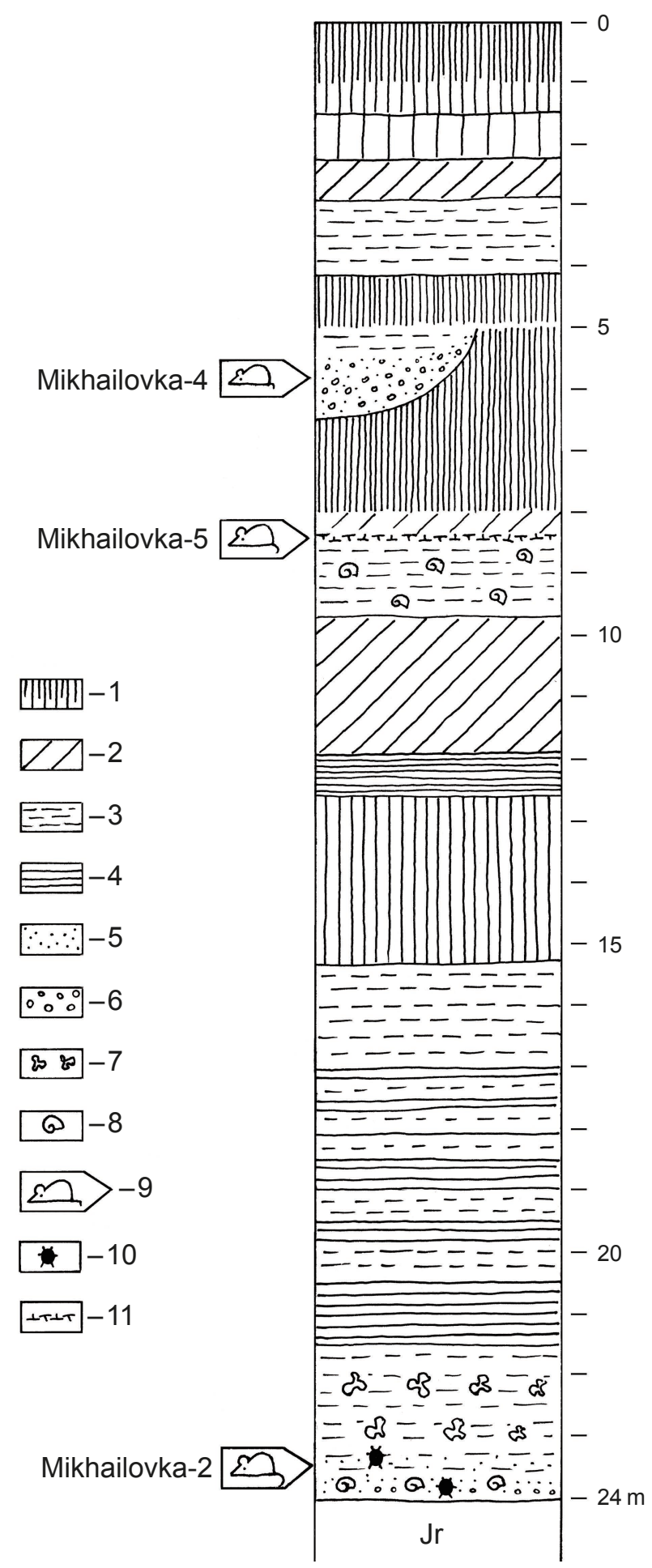

Text-fig. 4. Stratigraphic correlation of the five major fossil-bearing localities in the Mikhailovka quarry near Zheleznogorsk. 1 - loesses and soils, 2 - unlaminated loams, 3 laminated loams, 4 - clays, 5 - sands, 6 - gravels, 7 - carbonate concretions, 8 - mollusk shells, 9 - small mammal remains, 10 - insect remains, 11 - plant macroremains.

Further records are the Norway, the collared, and the steppe lemmings (Lemmus, Dicrostonyx, and Eolagurus); tundra vole (Microtus oeconomus); and field vole (Microtus agrestis). Ground squirrels (Spermophilus sp.) and steppe pika (Ochotona pusilla) are common. Shrew (Sorex sp.) and wood mouse (Apodemus ex gr. flavicollis/sylvaticus) are represented by single specimens. Most molars found at 
Mikhailovka-4 are morphologically nearly identical to those of modern species. The evolutionary levels of the water vole, the steppe lemming, and the narrow-headed vole, as well as the whole species composition indicate a Late Pleistocene age of the fauna.

Besides the small mammals, the bone-bearing horizon at Mikhailovka-4 contains large mammal bones in its gravel part, including postcranial bone and tooth fragments of the mammoth (Mammuthus sp.), woolly rhinoceros (Coelodonta antiquitatis), and reindeer (Rangifer tarandus) (Agadjanian 2009).

The faunal composition of Mikhailovka-4 is remarkable for is ecologically mosaic pattern. The dominance of the water vole (Arvicola cf. terrestris), tundra vole (Microtus oeconomus), and field vole (M. agrestis) indicates the presence of sedge and grass meadows. Wood mouse (Apodemus sylvaticus) and pine and red-backed voles (Microtus (Terricola) arvaloides, Clethrionomys glareolus) are consistent with woodland habitats, while ground squirrels (Spermophilus) and yellow steppe lemmings (Eolagurus) point to steppe-like conditions. To complicate this ecologically mixed pattern, collared and Norway lemmings are limited to shrubby tundra habitats, which is also indicated by the presence of the extinct mammoth (Mammuthus sp.), rhinoceros (Coelodonta antiquitati), and reindeer (Rangifer tarandus) (Agadjanian 2009). Overall, this combination is unusual for modern biota because of a coexistence of several major types of habitats in a single region. Most likely, the landscape was dominated by coniferous taiga forest with patches of steppe or tundra. The meadows were replaced by peat bogs in the lowest parts of the land. This combination of different types of biocenoses could not be stable over time and indicates that the fauna is transitional in nature and likely represents the final part of the Mikulino interglacial and the beginning of the Kalinin phase of the Valdayian glaciation (Agadjanian 2009) (Textfig. 4). It cannot be excluded that this faunal composition is influenced by taphonomical biases, but this seems to be unlikely since the formation of local alluvial deposits and the fauna accumulation typically happen during short intervals.

\section{Results}

\section{Mollusk fauna of Mikhailovka-5}

The rich mollusk fauna does not contain any extinct taxa and is dominated by terrestrial species ( $\mathrm{Pl}$. 1). For a complete list of molluskan taxa from Mikhailovka-5 see Table 1.

Mikhailovka-5 is the only locality in Russia so far that produced a large number of the terrestrial prosobranch mollusk Platyla polita. Today, this is mainly a western European thermophilous gastropod species. Western Belarus and western Ukraine (Likharev and Rammelmeyer 1952) are those regions of the recent range of this species that are situated closest to Mikhailovka. Platyla polita prefers moderately humid forests, where it inhabits soil litter (Welter-Schultes 2012). This species is known to occur in western and eastern European Holsteinian and Eemian faunas (Rousseau and Puisségur 1999, Alexandrowicz and Alexandrowicz 2010, Limondin-Lozouet et al. 2015), and its occurrence at Mikhailovka-5 suggests that the described fauna was formed during an interglacial. Both Carychium species (C. minimum, C. tridentatum) occur in large numbers at Mikhailovka-5, and outnumber most other mollusks. These gastropods have a broad ecological valence but require permanent humid conditions, similar to Platyla. They are found in humid woodlands and wet meadows. The Succinea species are found near water margins or at periodically flooded areas. Vallonia pulchella prefers swampy meadows; $V$. costata, which is numerous in Mikhailovka-5, prefers dry and open habitats with grassy and sunny slopes and often with rock rubble (Welter-Schultes 2012). Mikhailovka-5 is rich in woodland species, such as Acanthinula aculeata, clearly indicating the increased forestation that occurred at the time of the studied fauna and similar to the interglacial faunas of western Europe (Limondin-Lozouet et al. 2015). Acanthinula aculeata is a typical woodland species and is not found in open habitats, preferring deciduous forests with significant cover.

Mikhailovka-5 has an unusual abundance and diversity of Vertiginidae species. Vertigo pygmaea is widely distributed in modern-day Europe and prefers open habitats of variable humidity. V. pusilla is common in humid spots of otherwise dry woodlands and open forests. Notable is the abundance of $V$. substriata, which is characteristic for humid deciduous forests in Central Europe. The most abundant vertiginid is Vertilla angustior, which has a wide distribution in Europe and broad ecological preferences that depend significantly on the climate. It typically inhabits wet meadows and leaf litter in deciduous forests (Shileyko 1984). An interesting feature of the studied fauna is the presence of Truncatellina cylindrica, a species that inhabits leaf litter in warm, open, dry habitats, such as dry grasslands, and sand dunes.

Discus is a woodland species inhabiting a wide range of habitats from deciduous to coniferous forest, including montane and subalpine ones. Large numbers of the tiny Punctum pygmaeum are indicative of broadleaf forest habitats. This species presently has a strong association with beech (Fagus) forests on acid or calcareous soils (Likharev and Rammelmeyer 1952, Welter-Schultes 2012).

Clausilidae are rarely recorded in the Pleistocene faunas of the Russian Plain, so the occurrence of two species is notable. Macrogastra plicatula is a woodland species inhabiting wet habitats in both deciduous and coniferous forests. Ruthenica filograna is most common in west-central Europe (Transylvania), where it inhabits leaf litter in forest habitats (Likharev and Rammelmeyer 1952, Welter-Schultes 2012).

Overall, the terrestrial gastropod mollusk fauna is very diverse and mostly includes species typical of humid forest habitats. Several species indicate the presence of broadleaf (specifically beech) woodlands. The current distribution of several species in this fauna (i.e., Platyla polita, Ruthenica filograna) is south and west of the central Russian Plain, and the fauna bears resemblance to the Carpathian (Transylvanian) faunal complex (western Ukraine/Belarus/ Poland). The climatic and environmental conditions indicated by the mollusk fauna closely corresponds to those that existed during the Eemian in Europe (Turner 2000). The fauna existed in temperate conditions and does not contain extinct species typical of Middle Pleistocene 

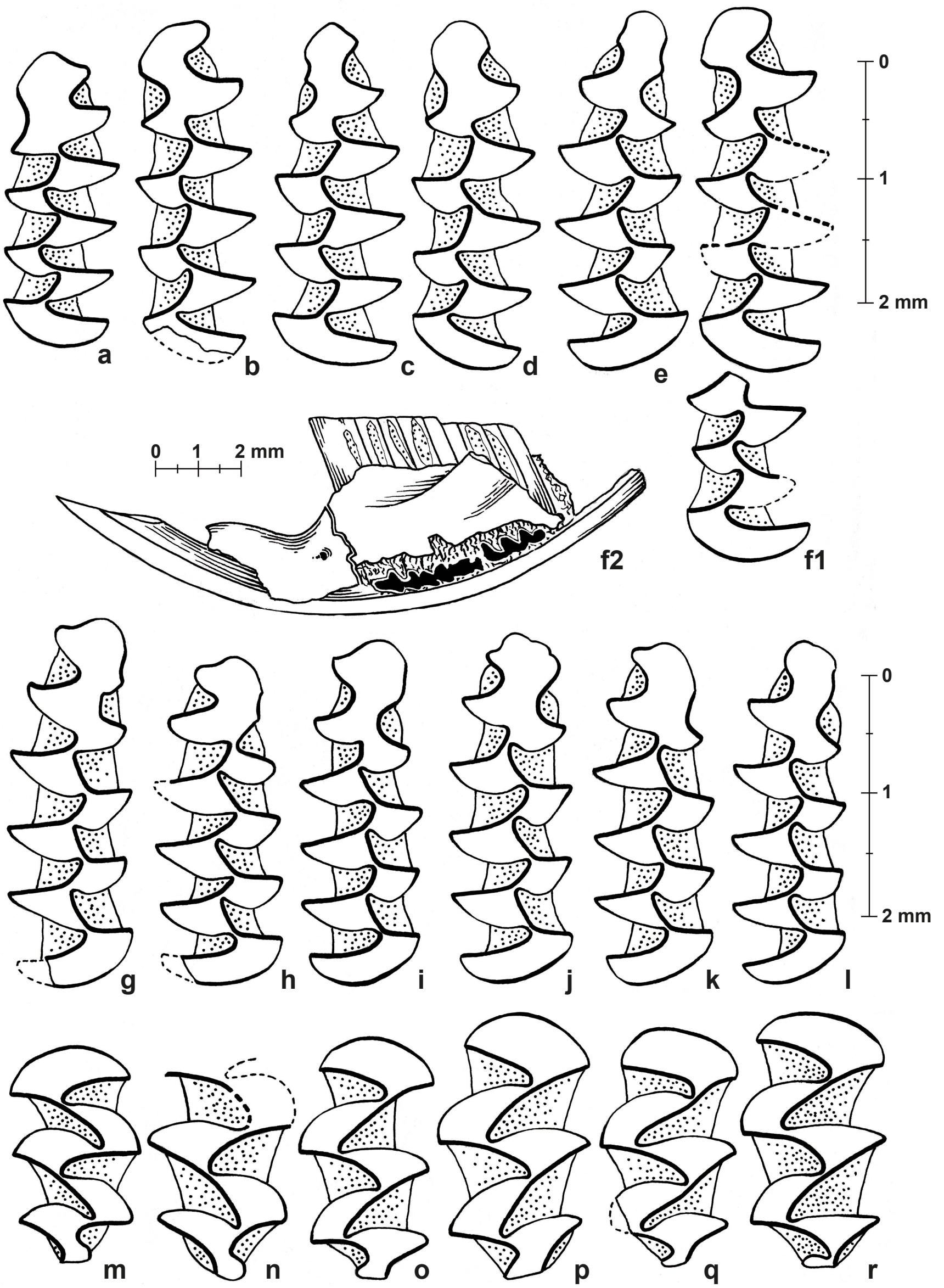

Text-fig. 5. Molars of Microtus ex gr. agrestis Linnaeus, 1761 from Mikhailovka-5. a-1: m1, m-r: M1. 
faunas. Its composition is very similar to other European Eemian molluskan faunas (Rousseau and Puisségur 1999, Alexandrowicz and Alexandrowicz 2010). For example, the Mikhailovka-5 fauna shares 15 terrestrial mollusk species $(75 \%)$ in common with Ruisseau de l'Amourette, an Eemian fauna in which Platyla, Carychium, and Vertigo also played a significant role (Rousseau and Puisségur 1999). The Mikhailovka-5 malacofauna differs significantly from that of the last Middle Pleistocene cold interval, as recorded, e.g., in the Batajnica fauna from Serbia (Osipova et al. 2013), in the late glacial faunas from Conty in northern France (Limondin-Lozouet and Antoine 2001), or in Halych in Western Ukraine (Alexandrowicz et al. 2014) in the presence of Platyla, clausilids, and different Vertigo species, while lacking the cold-adapted species such as Vertigo alpestris or Vallonia tenuilabris.

\section{Small mammal fauna of Mikhailovka-5}

One of the bone-bearing horizons in section 59 (layer 9, see chapter "Geologic setting and included faunas", Textfig. 3) at the Mikhailovka quarry belongs to the upper part of lacustrine deposits resting on a series of Likhvinian soils and covered with Mezin soils. These lacustrine deposits can be traced throughout the northern part of the quarry and have a thickness of 2-5 m. The small mammal fossils are mostly concentrated in thin lenses containing mollusk shells, humus material, and small carbonate concretions. Fossil material is well preserved and, in addition to isolated teeth, it frequently contains skull and jaw fragments and postcranial bones; most insectivore mandibles have intact coronoid processes. Nearly 500 small mammal fossils have been identified from Mikhailovka-5 (Tab. 2).

Mikhailovka-5 contains a diverse fauna of rodents and insectivores and is similar to other Eemian mammal faunas, as listed, e.g., by Markova (2000). Among rodents, the most numerous species are the field vole Microtus ex gr. agrestis $(21.7 \%)$ and the water vole Arvicola ex gr. sapidus (19.4\%). Molar morphology of Microtus ex gr. agrestis from Mikhailovka-5 has some archaic features that do not fully correspond to the modern $M$. agrestis. Present are also red-backed voles (Clethrionomys ex gr. glareolus) (6.1\%), mole rat (Spalax ex gr. microphtalmus) (5.9\%), and ground squirrel (Spermophilus) (3.6\%). Further notable is the presence of the pine vole morphologically close to the modern Microtus (Terricola) subterraneus and of the wood mouse (Apodemus ex gr. flavicollis/sylvaticus). Also the mole and the common shrew, morphologically close to modern Sorex araneus, are not rare. Lagomorphs are represented by the steppe pika Ochotona cf. pusilla.

The faunal diversity itself as well as the presence of insectivores, especially the mole (Talpa europaea), indicates temperate climatic conditions. Since we exclude intensive taphonomic biases, high numbers of the red-backed vole, wood mouse, and pine vole Microtus (Terricola) indicate the presence of extensive woodlands that contained conifers and broadleaf species. The abundance of Microtus ex gr. agrestis (Text-fig. 5) indicates the presence of meadows with diverse forbs. Most Arvicola species inhabit near-water habitats with abundant vegetation, especially sedges. Such habitats likely existed along the water bodies of the ancient valley. The presence of the mole rat, ground squirrel, and steppe lemming Eolagurus could indicate the presence of small areas with a steppe-like environment. It is therefore very likely that the fauna of Mikhailovka- 5 existed during a climatic optimum with environmental conditions similar to modern or even warmer conditions.

The age of Mikhailovka-5 can be correlated with MIS 5 based on the composition of the fauna. It lacks any species typical of Middle or Early Pleistocene such as Arvicola mosbachensis, Lagurus transiens, etc. (Agadjanian 2009), and the morphology of the represented species is very close to that of modern taxa. The key species of mammals from Mikhailovka-5 are still part of the modern fauna of the basins of the Dnieper, Desna, and Seima rivers today. Overall, the studied fauna is very close to the modern fauna, but detailed analysis reveals some peculiar differences. The distribution of such species as the steppe pika, narrow-headed vole, and yellow steppe lemming has been restricted to Asia since the early Holocene and does not include the European part of the Russian Plain (Gromov and Erbaeva 1995). The current distribution of the mole rat is also much further to the south along the Dnieper River, and during the Valday glaciation, it shifted even further south. Thus, the small mammal fauna of Mikhailovka-5 represents a peculiar zoogeographic pattern because it contains European and Asian temperate species.

Besides the faunal differences, there are morphological features that distinguish Mikhailovka-5 mammals from modern species. For example, Arvicola from Mikhailovka-5 has a molar structure that is intermediate in morphology between the Likhvinian Arvicola mosbachensis (SCHMIDTGEN, 1911) and modern Arvicola terrestris (LinNAEus, 1758) and is most similar to $A$. sapidus (see chapter "Two significant small mammal taxa from Mikhailovka-5"). The field vole Microtus ex gr. agrestis is more primitive than the modern Microtus agrestis from modern Central Russia in the structure of the accessory prism on M2 (see Agadjanian 2009 for details). Despite several differences in the structure of $\mathrm{m} 1$ and $\mathrm{m} 2$ between Microtus (Terricola) from Mikhailovka-5 and modern Microtus (Terricola) subterraneus (SELYsLongchamps, 1836) from the Central Russian Plain (see Agadjanian 2009), the Mikhailovka Terricola is much closer to the modern species than to the Early Pleistocene Terricola from the Dnieper and Don basins (see chapter "Two significant small mammal taxa..."). There are also subtle differences in the dental morphology between the ground squirrel and mole rat from Mikhailovka-5 and their modern counterparts (see Agadjanian 2009 for details).

Two significant small mammal taxa from Mikhailovka-5

\section{Microtus (Terricola) ex gr. subterraneus (Selys-Longchamps, 1836)}

M a te ri a l. PIN 4970/253-260, 8 m1; PIN 4970/261262, 2 m2; PIN 4970/263-268, 6 M3.

D e s c ription. Small vole teeth, rootless, with crown cement.

The opposing angles of the $\mathrm{m} 1$ paraconid complex are fused. The shape of the anterior part of the paraconid is variable (Text-fig. 6). The simplest morphotype has a single incoming angle on the medial side (Text-fig. 6). These teeth 

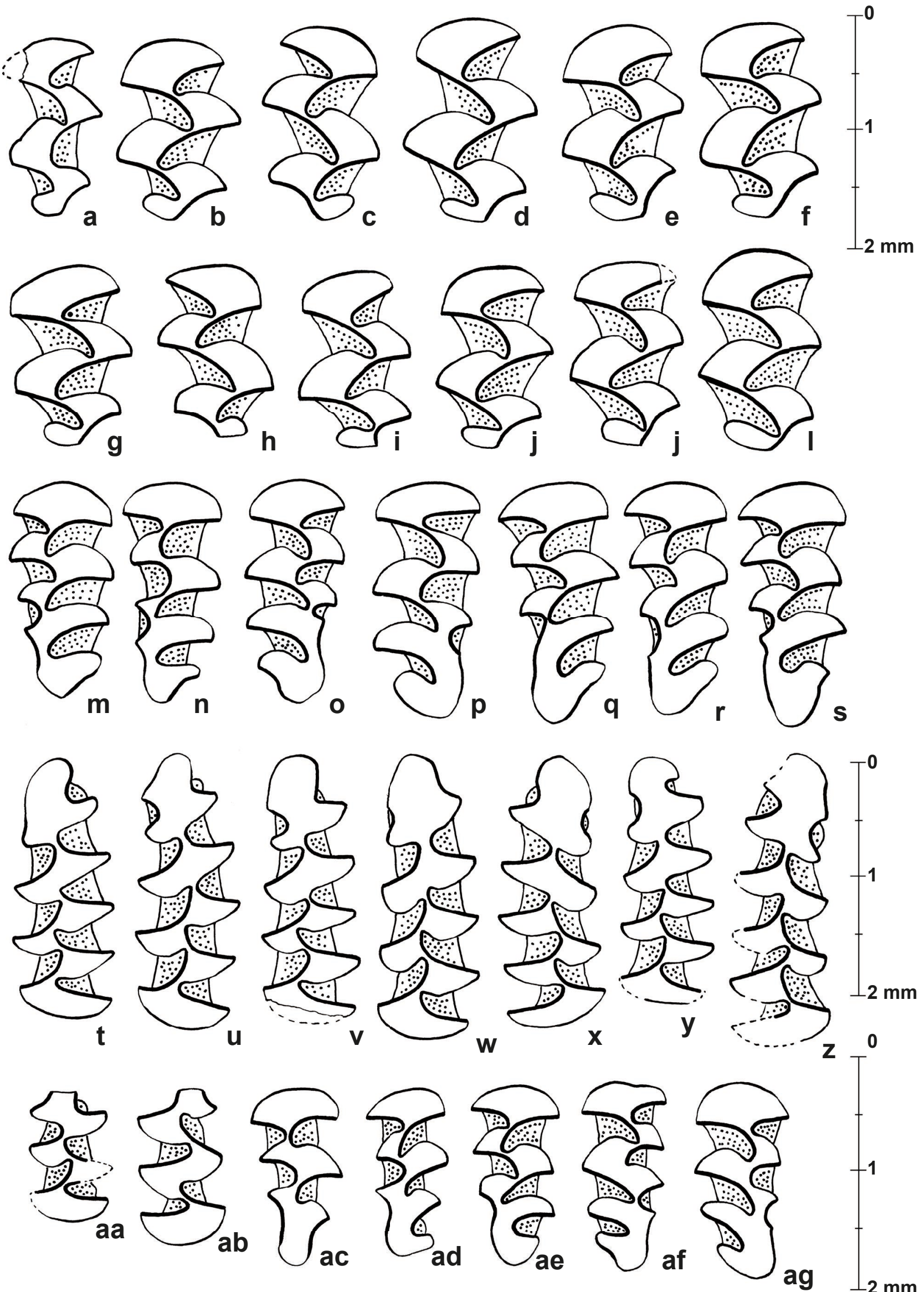

$12 \mathrm{~mm}$

Text-fig. 6. Molars of Microtus from Mikhailovka-5. Microtus ex gr. agrestis LinnaEus, 1761: a-l: M2, m-s: M3; Microtus (Terricola) ex gr. subterraneus (SElys-LongChamPs, 1836): t-z: m1, aa-ab: m2, ac-ag: M3. 
Table 3. Tooth measurements (in mm) of Microtus (Terricola) ex gr. subterraneus from Mikhailovka-5. Abbreviations: minmax - range, $n$ - number of specimens, $X$ - average, $x_{i}-$ single specimens.

\begin{tabular}{|l|c|c|c|c|c|}
\hline \multirow{2}{*}{} & \multicolumn{3}{|c|}{$\mathbf{m 1}$} & $\mathbf{m} \mathbf{2}$ & $\mathbf{M 3}$ \\
\cline { 2 - 6 } & $\mathbf{n}$ & $\mathbf{X}$ & $\mathbf{m i n}-\mathbf{m a x}$ & $\mathbf{x}_{\mathbf{i}}$ & $\mathbf{x}_{\mathbf{i}}$ \\
\hline Length & 7 & 2.38 & $2.2-2.5$ & $1.2 ; 1.35$ & $2.3 ; 2.3$ \\
\hline Width & 7 & 0.88 & $0.8-0.95$ & $0.8 ; 0.75$ & $0.75 ; 0.95$ \\
\hline
\end{tabular}

have a well-developed incoming angle on the lingual side of the paraconid head unlike Microtus (Terricola) gregaloides. This $\mathrm{m} 1$ structure in Microtus (Terricola) voles is found in the populations of $M$. (Terricola) duodecimcostatus and M. (Terricola) lusitanicus from the Late Pleistocene of southwestern Europe (Chaline 1972). Other variations in the $\mathrm{m} 1$ structure include two incoming angles on the lingual and labial sides of the paraconid head that can be either weak or well developed. In the latter case, the distance between the apices of the angles is less than the anterior width of the paraconid head, which is more typical for modern $M$. (Terricola) subterraneus. See Table 3 for measurements.

The $\mathrm{m} 2$ structure is typical of most Microtus sensu lato except for the fusion of the first pair of the opposing triangles and, in one case, of the second pair also, which is characteristic of Terricola.

The M3s are the smallest teeth of all arvicoline M3 from Mikhailovka-5. Some of them show fusion of paracone with the hypocone and/or hypocone with the metacone. Few specimens have a simple posterior loop without the incoming angles, which is more typical of early Middle Pleistocene Microtus (Terricola).
Comparison and comments. Microtus (Terricola) voles were widely distributed in the Russian Plain during the Middle Pleistocene (Gromov and Polyakov 1977). Small populations persist in this region still today, which allows detailed morphological comparisons. Middle Pleistocene Microtus (Terricola) are mostly represented by the Microtus (Terricola) gregaloides morphotype, which is characterized by a small rounded paraconid head with a small incoming angle on the lingual side on $\mathrm{m} 1$ (Agadjanian 2009). However, this morphotype has not been found in Mikhailovka-5 and is not present in the modern populations of Microtus (Terricola).

Late Middle Pleistocene populations of Microtus (Terricola) are characterized by morphotypes similar to Microtus (Terricola) gregaloides and Microtus (Terricola) arvaloides, but the latter is more common (Agadjanian 2009), which is also the case for the Terricola from Mikhailovka-5. In addition to the above-mentioned morphotypes, Likhvinian populations of Microtus (Terricola) (Vladimirovka locality on the Don River) also contain the Microtus (Terricola) duodecimcostatus morphotype. The dental morphology of the modern pine vole Microtus (Terricola) subterraneus is significantly different. Their $\mathrm{m} 1$ is similar to Microtus (Terricola) arvaloides, but the incoming angles on the paraconid head are much better developed. Modern Terricola also have a different $\mathrm{m} 2$ structure, where the dentine fields of the opposing triangles merge with each other. Moreover, the M3 of modern Microtus (Terricola) often has fused opposing triangles and paracone and hypocone are also fused. This $\mathrm{m} 2$ and M3 morphology does not occur in Middle Pleistocene Microtus (Terricola) (Agadjanian 2009). Thus, Microtus (Terricola) from Mikhailovka-5 differs significantly from the Middle Pleistocene Microtus (Terricola) in the structure of $\mathrm{m} 1, \mathrm{~m} 2$, and M3. Its morphology is overall similar to the

Table 4. Tooth measurements (in mm) of Arvicola ex gr. sapidus from Mikhailovka-5. Abbreviations: $\mathbf{n}$ - number of specimens, $\mathrm{X}$ - average, index $\mathrm{H} / \mathrm{L}$ - height/length; min-max - range, s - standard deviation, $\mathrm{V}$ - coefficient of variation.

\begin{tabular}{|c|c|c|c|c|c|c|c|c|c|c|}
\hline & \multicolumn{5}{|c|}{ m1 } & \multicolumn{5}{|c|}{$\mathbf{m} 2$} \\
\hline & $\mathbf{n}$ & $\mathbf{X}$ & $\min -\max$ & $\sigma$ & V & $\mathbf{n}$ & $\mathbf{x}$ & $\min -\max$ & $\sigma$ & V \\
\hline Length & 11 & 3.82 & $3.45-4.40$ & 0.284 & 7.4 & 12 & 2.26 & $2.0-2.5$ & 0.135 & 5.97 \\
\hline Width & 11 & 1.53 & $1.35-1.65$ & 0.106 & 6.9 & 12 & 1.39 & $1.25-1.5$ & 0.109 & 7.8 \\
\hline Height & 11 & 5.29 & $4.5-6.40$ & 0.68 & 12.8 & 12 & 4.38 & $3.3-5.6$ & 0.63 & 14.40 \\
\hline \multirow[t]{3}{*}{ Index $H / L$} & 11 & 1.38 & $1.25-1.43$ & 0.099 & 7.16 & 12 & 1.93 & $1.65-2.33$ & 0.206 & 10.66 \\
\hline & \multicolumn{5}{|c|}{$\mathbf{m 3}$} & \multicolumn{5}{|c|}{ M1 } \\
\hline & $\mathbf{n}$ & $\mathbf{X}$ & $\min -\max$ & $\sigma$ & V & $\mathbf{n}$ & $\mathbf{x}$ & $\min -\max$ & $\sigma$ & V \\
\hline Length & 9 & 2.1 & $1.75-2.35$ & 0.206 & 9.76 & 13 & 3.26 & $2.9-3.7$ & 0.268 & 8.2 \\
\hline Width & 9 & 1.06 & $0.9-1.2$ & 0.099 & 9.36 & 17 & 1.66 & $1.25-1.85$ & 0.159 & 9.5 \\
\hline Height & 9 & 9.36 & $2.8-3.75$ & 0.456 & 13.9 & 16 & 1.49 & $3.4-6.15$ & 0.957 & 18.2 \\
\hline \multirow[t]{3}{*}{ Index $H / L$} & 9 & 1.55 & $1.48-1.83$ & 0.159 & 10.24 & 13 & 1.61 & $1.17-1.89$ & 0.223 & 13.79 \\
\hline & \multicolumn{5}{|c|}{ M2 } & \multicolumn{5}{|c|}{ M3 } \\
\hline & $\mathbf{n}$ & $\mathbf{X}$ & $\min -\max$ & $\sigma$ & $\mathbf{V}$ & $\mathbf{n}$ & $\mathbf{X}$ & $\min -\max$ & $\sigma$ & V \\
\hline Length & 14 & 2.42 & $2.25-2.7$ & 0.14 & 0.14 & 10 & 2.2 & $1.7-2.5$ & 0.21 & 9.6 \\
\hline Width & 16 & 1.49 & $1.3-1.7$ & 0.115 & 7.69 & 10 & 1.14 & $0.9-1.3$ & 0.117 & 10.2 \\
\hline Height & 16 & 5.06 & $3.70-6.15$ & 0.93 & 8.3 & 9 & 4.06 & $2.9-4.65$ & 0.64 & 15.8 \\
\hline Index H/L & 14 & 2.1 & $1.64-2.47$ & 0.333 & 15.8 & 9 & 1.83 & $1.6-2.15$ & 0.185 & 10.14 \\
\hline
\end{tabular}



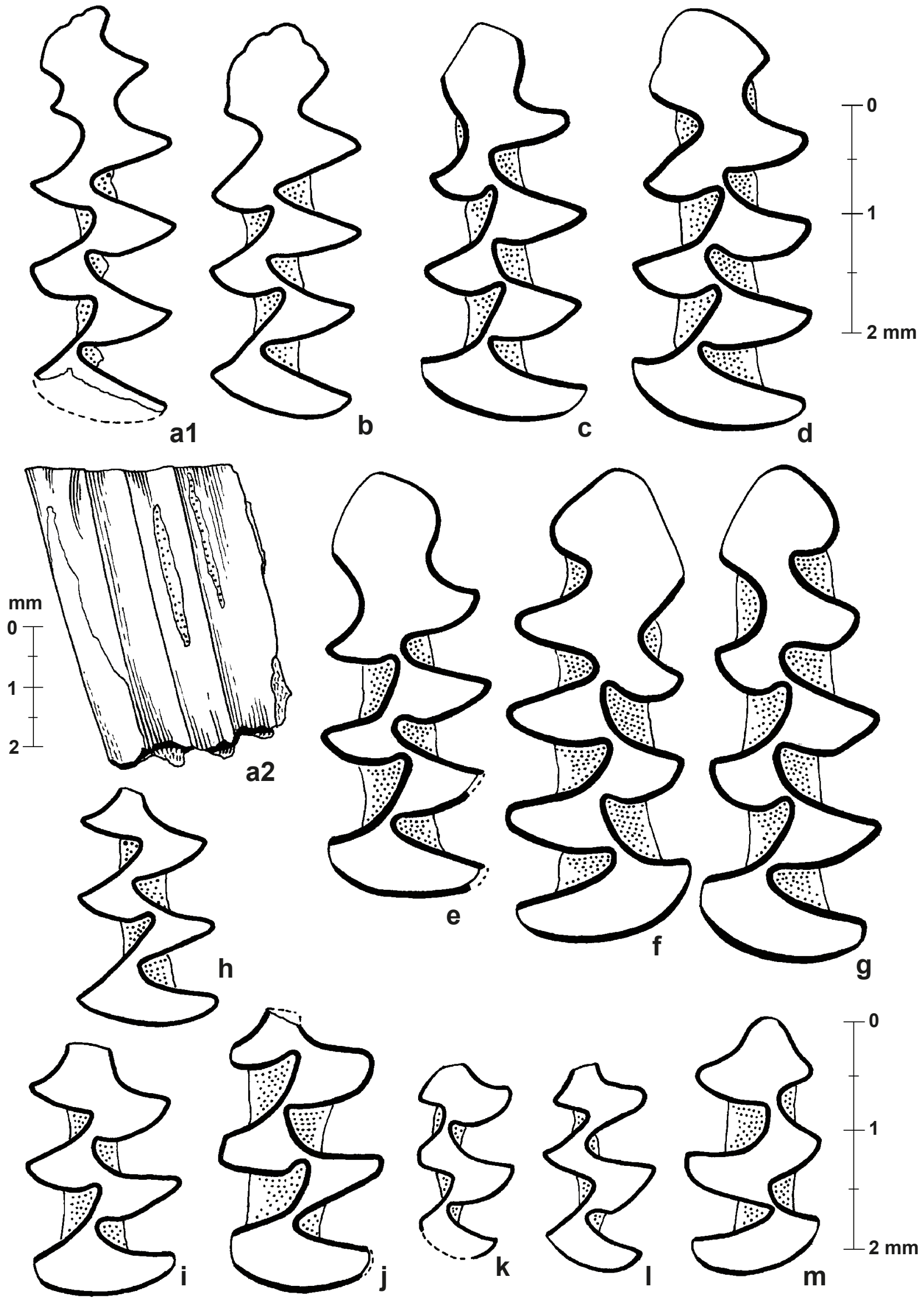

Text-fig. 7. Lower molars of Arvicola ex gr. sapidus MiLler, 1908 from Mikhailovka-5. a-g: m1, h-j: m2, k-m: m3.

28 

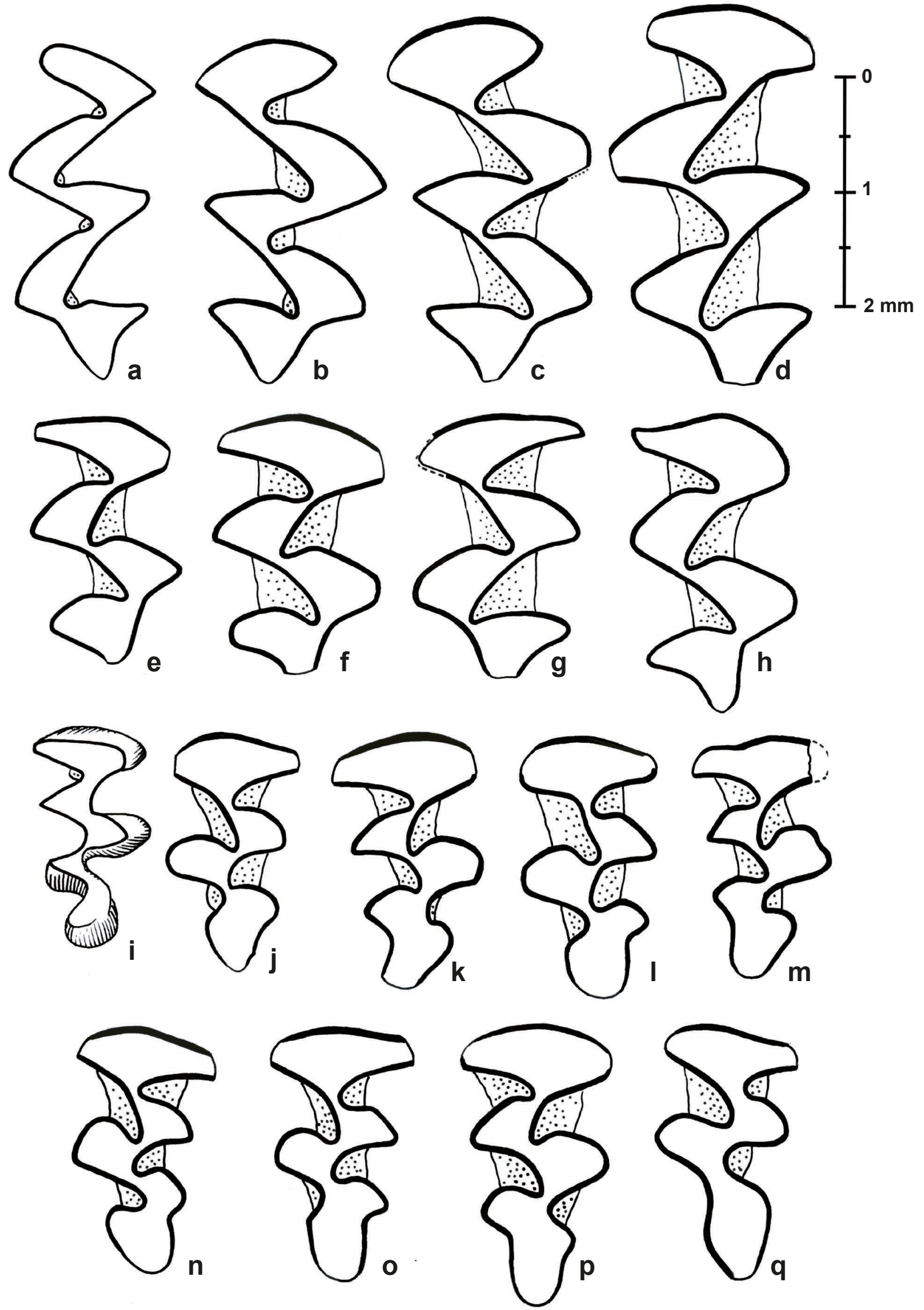

Text-fig. 8. Upper molars of Arvicola ex gr. sapidus Miller, 1908 from Mikhailovka-5. a-d: M1, e-h: M2, i-q: M3. 
modern Microtus (Terricola) subterraneus from the Russian Plain but differs by having a few archaic traits. More material is needed to determine the exact taxonomic position of Microtus (Terricola) from Mikhailovka-5.

\section{Arvicola ex gr. sapidus Miller, 1908}

M a t e ri a l. PIN 4970/117-137, 21 m1; PIN 4970/138158, 21 m2; PIN 4970/159-174, 16 m3; PIN 4970/175-199, 25 M1; PIN 4970/200-222, 23 M2; PIN 4970/223-240, 18 M3; PIN 4970/241-243, 3 calcanei; PIN 4970/ 244-246, 3 tali; PIN 4970/247-251, 5 ulnae; PIN 4970/252, 1 humerus.

D e s c r i p t i o n. Water vole teeth from Mikhailovka-5 are similar to the modern Arvicola terrestris in size. Crown cement is well developed on teeth of older individuals. Molars, especially $\mathrm{m} 1$ and $\mathrm{M} 3$, are variable in size and morphology (Text-figs 7, 8). On almost all teeth, the enamel has the same thickness on anterior and posterior enamel edges. It is thinner in younger teeth compared to those of older individuals (Tab. 4).

Of the $21 \mathrm{~m} 1$, only 1 belonged to a younger individual. The anterior part of the paraconid bears a fold resembling a "Mimomys" fold (Text-fig. 7), which disappears when tooth crown wear exceeds $20 \%$. The same younger tooth has a dentine track on the labial side of the paraconid. This track reaches the occlusal surface on the worn teeth. The $\mathrm{m} 2 \mathrm{~s}$ are characterized by the fusion of the first pair of the opposing triangles. The $\mathrm{m} 3 \mathrm{~s}$ have both the first and second pairs of opposing triangles fused.

Both M1 and M2 have clearly separated triangles on the occlusal surface and are not different from the corresponding teeth of the other representatives of the genus. M3 has a unique structure. There is a significant variation in the complexity of the posterior part of the tooth.
Some of the specimens have a simple, oval-shaped posterior lobe (metacone and posterior loop), while the others have a complex posterior lobe with convex outer walls and complex posterior loop. The teeth of younger individuals indicate that this differentiation is better expressed during the earlier stages of development. The more complex morphotypes have two external cement columns in the incoming angles on each side of the tooth, and the simpler types can have one on the lingual and two on the labial side. Few specimens show a tendency for the fusion of the triangles.

Comparison and comments. Molars of Late Pleistocene water voles were larger than those of Middle Pleistocene ones. Table 5 contains measurements of Pleistocene and modern species of Arvicola showing that A. mosbachensis from the Middle Pleistocene was the smallest in the genus. Arvicola from the first half of the Late Pleistocene including those of Mikhailovka-5 were much larger, but not as big as the modern A. terrestris. Although there are not enough specimens for a detailed statistical analysis, the trend can be established based on data from previous studies (Agadjanian 1983, Agadzhanyan 2012).

The taxonomic position of Arvicola from Mikhailovka-5 is determined by the occlusal pattern of its $\mathrm{m} 1$ and M3. Published data indicate that 20-25\% of the m1s of $A$. mosbachensis from Holsteinian have a "Mimomys" fold on the paraconid (Radulesco and Samson 1977, Agadjanian 1983), but in modern Arvicola only 2-3 \% show this feature. In Mikhailovka-5, the fold was present only on $1 \mathrm{ml}$ out of $21(\sim 5 \%)$.

M3 provides additional information about the identity of the Arvicola from Mikhailovka-5. The posterior part of this tooth in the Middle Pleistocene A. mosbachensis is significantly lobed, and the incoming angles between the metacone and posterior loop are deep, causing a separation

Table 5. Comparison of $\mathrm{m} 1$ and M3 length in different species of Arvicola (in mm). Abbreviations: max - highest value, min - least value, $\mathrm{X}$ - average.

\begin{tabular}{|l|l|c|c|}
\hline \multicolumn{1}{|c|}{ Species } & \multicolumn{1}{|c|}{ Age } & \multicolumn{1}{|c|}{$\begin{array}{c}\text { m1 length } \\
\text { min/X/max }\end{array}$} & $\begin{array}{c}\text { M3 length } \\
\text { min/X/max }\end{array}$ \\
\hline A. mosbachensis, Mosbach (1) & Middle Pleistocene & $3.0 / 3.3 / 3.7$ & \\
\hline A. greeni, Mosbach (1) & Middle Pleistocene & $3.0 / 3.2 / 3.6$ & \\
\hline A. cantiana, Petersbuch (2) & Middle Pleistocene & $3.4 / 3.5 / 3.6$ & \\
\hline A. cantiana, Tarkö (3) & Middle Pleistocene & $3.1 / 3.16 / 3.3$ & \\
\hline A. cantiana, Rotbav-Dedul (4) & Middle Pleistocene & $3.12 / 3.42 / 3.8$ & $1.7 / 2.05 / 2.2$ \\
\hline A. mosbachensis, Strelitza (5) & Likhvinian & $2.9 / 3.45 / 3.7$ & $1.95 / 2.21 / 2.5$ \\
\hline A. mosbachensis, Vladimirovka-2 (6) & Likhvinian & $2.9 / 3.44 / 3.7$ & $2.15 / 2.29 / 2.5$ \\
\hline A. mosbachensis, Vladimirovka-1 (6) & Likhvinian & $3.4 / 3.6 / 3.8$ & $2.1 / 2.28 / 2.4$ \\
\hline A. mosbachensis, Chigirin (7) & Likhvinian & $3.2 / 3.49 / 3.9$ & $2.1 / 2.23 / 2.5$ \\
\hline A. mosbachensis, Gunki 1 (7) & Likhvinian & $3.15 / 3.43 / 3.7$ & $1.95 / 2.44 / 3.15$ \\
\hline A. cf. sapidus, Komintern (6) & Moskva (Riss 2) & $3.0 / 3.64 / 4.15$ & $1.7 / 2.2 / 2.5$ \\
\hline A. ex gr. sapidus, Mikhailovka-5 & Mikulino (= Eemian) & $3.45 / 3.82 / 4.41$ & $2.4 / 2.84 *$ \\
\hline A. terrestris & modern & $3.94 / 4.37 *$ & \\
\hline
\end{tabular}

(1) Heller 1969, (2) von Koenigswald 1970, (3) Jánossy 1976, (4) Radulesco and Samson 1977, (5) Agadjanian 1983, (6) Agadjanian 2009, (7) Markova 1982.

* Variability of the mean measurements in different Palaearctic populations is based on data from Agadjanian (2009). 
of these prisms on some specimens. In modern Arvicola, the posterior triangle is fused with the metacone. Based on this feature, the Arvicola from Mikhailovka-5 is intermediate between the archaic and modern Arvicola, being different from both. It resembles more A. sapidus from southwestern Europe (Agadjanian 2009). Based on previous studies (Agadjanian and Erbaeva 1983), this species displays an array of primitive dental morphological features. Moreover, its number of chromosomes $(2 \mathrm{n}=40)$ is different from A. terrestris $(2 \mathrm{n}=36)$ (Reichstein 1963), indicating it is a relic species that survived on the Iberian Peninsula. This species has been identified from the Late Pleistocene of northwestern Spain (López-García et al. 2011) and southern France (Montuire and Desclaux 1997). Eemian Arvicola is common in central and southern England (Sutcliffe and Kowalski 1976), France (Chaline 1972), Central Europe (Jánossy 1985, van Kolfschoten 2000), and nearly all localities across the Russian Plain (Markova 2000, Agadjanian 2009). Despite the similarity to $A$. sapidus, the water vole from Mikhailovka-5 represents a distinct taxon, here referred to as Arvicola ex gr. sapidus. It was likely widespread across Eastern Europe during the Mikulino interglacial. The taxonomy of Pleistocene Arvicola is complicated and Schmelzband-DifferenzierungsQuotient was shown to be unreliable in species identification (Escudé et al. 2008a), so morphology is the only reliable key to identification (Agadjanian 1983, Agadzhanyan 2012). It has been even suggested that all Pleistocene Arvicola belonged to a single species, Arvicola cantiana (Escudé et al. 2008a, b), which is an oversimplification. The evolution of Middle and Early Pleistocene Arvicola was complex and likely involved several transitional species (Agadzhanyan 2012), including the vole present in the Mikhailovka-5 fauna.

\section{Comparison of the Mikhailovka-5 fauna with other Eemian small mammal faunas}

Late Pleistocene small mammal faunas have been known since the nineteenth century, mostly from archaeological excavations. These faunas were used to determine the geochronological position and the dynamics of environmental changes (Lyell 1872). A similar approach was used by Nehring (1890), who introduced the concept of tundra-steppe for the landscapes of the Last glaciation of Central Europe. Since then, small mammal faunas have been widely used for stratigraphy and palaeogeographic reconstructions during the Pleistocene. Similarly, mollusk faunas also became an important source of data for such reconstructions (Fejfar and Ložek 1957, Ložek 1964). Hundreds of small mammal faunas are known from the Late Pleistocene of Western, Central, and Eastern Europe, the Ural Mountains, Western and Eastern Siberia, and the Altai Mountains (Agadjanian 2009). The majority of these faunas are associated with Middle and Late Palaeolithic localities, mostly correspond to the second half of the Late Pleistocene, and are limited to the Valdayian glacial. The faunas of the first half of the Late Pleistocene that belong to the Mikulinian $(=$ Eemian $=$ Ipswichian $)$ interglacial are much less studied and rarely include data for both small mammals and mollusks, which makes the current study rather singular.

A review of the Eemian mammal faunas of Central Europe lists nine known localities of this age (van
Kolfschoten 2000); Markova mentioned 15 Mikulinian localities from the Russian Plain and the Crimea (Markova 2000). There are few Riss-Würm (= Eemian) faunas, such as Santenay, Montignac, Combe-Grenal, and Baume MoulaGuercy known from France (Chaline 1972, Defleur and Desclaux 2019). In Hungary, the upper strata of the Süttö locality can be referred to this age (Jánossy 1985), indicating that the faunas of the last interglacial are uncommon in the fossil record. This lack in the fossil record is probably the result of a warm and humid climate that increases the rate of decomposition of fossil remains because it produces more favourable conditions for bacteria, fungi, and various invertebrates, including worms and insect larvae, than the dry and cold climate that is typical for glacial periods. Personal observations in the modern tundra indicate that decomposition is much slower than in Central Russia, where a dead mole becomes buried in the ground to a depth of $10 \mathrm{~cm}$ overnight by scavenging beetles. Further, the formation of extensive forests and dense grass cover in the open landscapes decrease the erosion of the ground, which slows the formation and thanatocenoses and taphocenoses, i.e., the rate of fossilization that accounts for the rarity of such faunas described for Mikhailovka- 5 and increases their significance.

The fauna of Mikhailovka-5 is similar to that of other Mikulinian localities. These faunas are characterized by the abundance and diversity of insectivores, which often account for up to $10 \%$ of small mammal remains. These similarities most likely reflect true faunal composition as fossil accumulation in the studied localities was not due to owl activity or selective deposition that you often observe in cave deposits (Andrews 1990). Eemian faunas, such as those of Santenay (France), Süttö (Hungary), Schönfeld and Stuttgart-Untertürkheim (Germany), and Borisova Gora (Belarus) (Chaline 1972, Jánossy 1985, Sanko and Motuzko 1991, van Kolfschoten 2000), typically contain shrews Sorex and Neomys and moles Talpa.

The bulk of the small mammal fossil assemblage at Mikhailovka-5 is formed of voles. Nearly all European small mammal faunas of this age are dominated by Microtus voles with $M$. arvalis and $M$. ex gr. agrestis being the most common (Agadjanian 2009). Notably, these species are absent from the second half of the Middle Pleistocene of the Russian Plain or are represented by much more archaic morphotypes (Agadjanian 2009). Another vole that is typical representative of the Mikhailovka-5 fauna is Microtus (Terricola) ex gr. subterraneus, which is morphologically quite different from the Middle Pleistocene Terricola and much closer to the modern species. Microtus (Terricola) subterraneus is known from the Borisova Gora locality in Belarus (Sanko and Motuzko 1991), Gröbern 1 and Taubach in Germany (van Kolfschoten 2000), and layers 2 and 3 at the Süttö 6 locality in Hungary (Jánossy 1985). Microtus (Terricola) subterraneus has been reported from several Eemian localities in France, including Santenay (layers 5a, 5c, and 3), Regourdou (layers 2 and 7) and others (Chaline 1972). This species was rather broadly distributed in Central and Southern regions of Western Europe in both Middle and Late Pleistocene (Schreve 2001, Bogićević et al. 2012), but was only present in the central part of the Russian Plain during the Eemian (Agadjanian 2009). 
Clethrionomys voles are strong indicators of forested habitats and have been reported from 8 of the 15 Mikulian faunas of the Russian Plain (Markova 2000). In the faunas of Borisova Gora and Konevich, they are the dominating species (Kalinovski 1983, Markova 2000). Clethrionomys have been reported from 5 of the 9 Eemian localities in Germany (van Kolfschoten 2000) and from several Eemian faunas in France, including Santenay (layers 5a, 5c and 3), and Regourdou (layers 8, 7, 5, and 2) (Chaline 1972). Their abundance reaches $6 \%$ at Mikhailovka-5.

Water vole Arvicola has been present in European small mammal faunas since the second half of the Middle Pleistocene until present. The evolution and morphology of this group of voles has been described in detail, including changes in the enamel molar structure that began during the Likhvinian $(=$ Holsteinian $=$ Hoxnian $)$ interglacial and continue through the present time (von Koenigswald 1973, Heinrich 1982, Agadjanian 1983, Desclaux et al. 2000, Agadjanian 2001, 2009, Agadzhanyan 2012). These changes included a transition from Mimomys-type of enamel differentiation to the Microtus-type, i.e., a transition from late Mimomys to the first Arvicola mosbachensis of the Likhvinian and to the molars that are typical for the modern Arvicola terrestris. Notably, the Mikulinian water voles have an enamel structure intermediate between $A$. mosbachensis and $A$. terrestris, which is seen among modern water voles only in the Arvicola sapidus from southern France and the Iberian peninsula (Agadjanian 2009). It is likely that modern A. sapidus is a relic species from the Eemian with a more archaic morphology and karyotype (Reichstein 1963). Interesting data have been reported from the Biśnik Cave locality in Poland. Arvicola is present in all strata from the late Middle to Upper Pleistocene, including the Weichselian (= Valdayian) glacial, but reaches the highest representation in layer 13, which was referred to MIS 5e and thus is Eemian in age (Socha 2014). In this layer, the enamel differentiation (SDQ) index that characterizes the molar enamel structure is

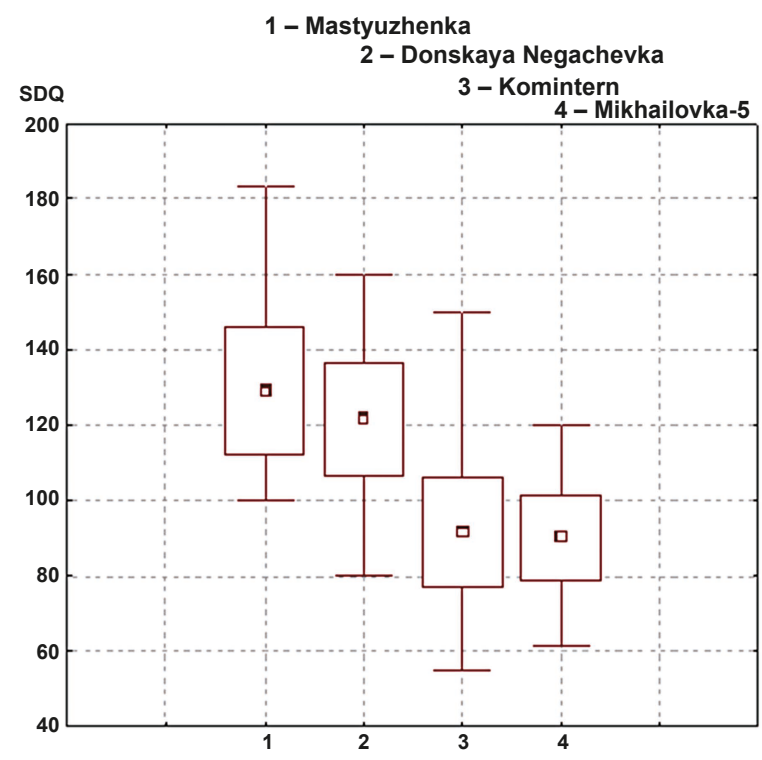

Text-fig. 9. Enamel differentiation index (SDQ) of Likhvinian $(1,2)$ and Mikulinian $(3,4)$ samples of Arvicola from the Russian Plain. very close to that of the Arvicola from Mikhailovka-5 (Textfig. 9). The SDQ index of molar enamel of the Arvicola amphibius (= terrestris) from layers 14 and 15 of Biśnik Cave (Socha 2014) indicates enamel of equal thickness across the molars, which is more typical for $A$. sapidus. Of the six Ipswichian localities from England, three represent a "transitional form" (Sutcliffe and Kowalski 1976) between Arvicola cantiana (= A. mosbachensis) and A. terrestris, which is very close to $A$. sapidus.

Small numbers of the wood mouse Apodemus ex gr. sylvaticus were recorded from Mikhailovka-5. This species is closely associated with broadleaf deciduous forests (Gromov and Erbaeva 1995). It is present in dozens of Late Pleistocene localities of the British Isles, where they are found in all temperate interglacial fossil assemblages of the Late Pleistocene (Sutcliffe and Kowalski 1976). Wood mice were very common in the Upper Pleistocene deposits of Northern Italy and Spain (López-García et al. 2011, 2014) and of Central Europe (Jánossy 1985, van Kolfschoten 2000, Döppes et al. 2008). Apodemus is much less common on the Russian Plain (Markova 2000) but reaches significant numbers at the Borisova Gora in Belarus (Sanko and Motuzko 1991).

Despite the overall similarities between Eemian faunas across Europe, there are a few differences. For example, the Mikhailovka-5 fauna does not contain any dormice (Gliridae), which is also true for most localities on the Russian Plain, except for the Borisova Gora site in Belarus. But even then, only 2 specimens out of 957 identified were referred to Glis sp. (0.2\% of the total) (Markova 2000). Of the nine Central European Eemian localities, dormice (Glis glis) was only identified at Burgtonna (van Kolfschoten 2000). The only hazel dormouse (Muscardinus) tooth in England was found in the stratotypic section of the Cromerian in the Cromer Forest bed of Norfolk (Sutcliffe and Kowalski 1976). Muscardinus avellanarius are known from the Holocene cave deposits of England but are absent from the Late Pleistocene faunas. Dormice are common in the Eemian deposits of Spain, France, Italy, Hungary, and Poland, where at least three species, Eliomys quercinus, Muscardinus avellanarius, and Glis glis, have been identified (Chaline 1972, Jánossy 1985, López-García et al. 2011, 2014, Socha 2014).

A distinctive feature of the Mikhailovka-5 fauna is the presence of the yellow steppe lemming Eolagurus. This rodent is typical for dry steppe habitats and is currently found in the Zaisan Depression of Kazakhstan, Western Mongolia, Northwestern China, and Inner Mongolia (Gromov and Erbaeva 1995). The distribution of Eolagurus in the beginning of the Middle Pleistocene stretched from the lower reaches of the Volga and Don rivers to the lower reaches of the Dnieper and Dniester rivers (Gromov and Baranova 1981). Eolagurus cf. luteus has been identified from 6 of the 15 Mikulinian localities on the Russian Plain and Crimea (Markova 2000).

An unusual component of the Mikhailovka-5 fauna is the presence of the mole rat Spalax ex gr. microphtalmus. Besides Mikhailovka, this subterranean rodent has been identified from only one Eemian locality on the Russian Plain and Crimea, the El'tigen site in the Crimea (Markova 2000). The mole rat is rare in corresponding faunas of Poland 
and Hungary and is completely absent from those of Central Europe, Great Britain, Spain, France, and Italy.

Another distinctive component of the Mikhailovka-5 fauna is the ground squirrel Spermophilus ex gr. suslicus. This rodent species does not occur in the Eemian faunas of Central Europe, Italy, Spain, or England; but one species of ground squirrel, Citellus citelloides, has been recorded from Süttö 6 in Hungary (Jánossy 1985). Ground squirrels are known from Poland, and Citellus sp. of Eemian age has been reported from the Grotte Scladina in Belgium (Döppes et al. 2008).

A distinctive feature of the cold epochs of the Late Pleistocene Eastern European faunas is the presence of jerboas; they were broadly distributed during that time and reached the upper Volga River, which is $400-500 \mathrm{~km}$ north of Moscow (Agadjanian 2009). However, they are rare in the Mikulinian interglacial faunas and are known from the Shkurlat fauna from the Don River and the Zaskalnaya IX fauna from the Crimea (Markova 1986, 2000). The Crimean peninsula marked the westernmost distribution of jerboas during the Late Pleistocene.

Lagomorphs in the Mikhailovka-5 fauna are represented by the steppe pika Ochotona cf. pusilla. Pikas were common in the Late Pleistocene faunas of Asia and Eastern Europe, but in small numbers and mostly during the cold epochs. They were much rarer during the Eemian interglacial. Of 15 Mikulinian localities on the Russian Plain and Crimea, Ochotona pusilla has been recorded in only five (Markova 1986, 2000). Pikas have not been described from the Eemian faunas of Central and Western Europe.

Thus, overall the Mikhailovka-5 small mammal fauna is generally similar to the other Eemian faunas of the Russian Plain, but it differs in the presence of steppe species. The studied fauna also differs from the Eemian small mammal faunas of Central and Western Europe in records of ground squirrels, mole rats, and yellow steppe lemmings, but missing typical Mediterranean species, such as the porcupine and dormice.

\section{Palaeoenvironmental reconstructions}

The Mikhailovka-5 locality consists of lacustrine deposits that were formed during the first half of the Mikulino interglacial (Glushankova 2008a). These deposits include the Mezin fossil soil, which is recorded in layers 5 and 6 in section 59. It contains significant amounts of organic materials and silica, indicating a pseudopodsol soil type, which is, e.g., typical for the broadleaf forest zone of Central Europe (Gerasimov 1960).

Such a palaeoenvironment concluded from the soil type is consistent with the mollusks and small mammal faunas from the bone-bearing horizon of Mikhailovka-5. The mollusk assemblage is dominated by species typical of a warm and humid climate, which prefer broadleaf forests: Platyla polita, both recorded species of Carychium, Acanthinula aculeata, Discus sp., Punctum pygmaeum, which presently has a strong association with beech (Fagus) forests, and the clausilids Macrogastra plicatula and Ruthenica filograna.

Small mammal species that are indicative for forests are Apodemus ex gr. sylvaticus, Clethrionomys glareolus,
Microtus (Terricola) ex gr. subterraneus, Talpa ex gr. europaea, and Sorex ex gr. araneus (Görner and Hackethal 1988). Among these species, red backed vole, mole, and common shrew occur in other habitats as well, but reach their highest density in broadleaf forests. Apodemus sylvaticus and Microtus (Terricola) subterraneus are widely distributed in Europe but on the Russian Plain are mostly limited to the zone of broadleaf forests (Gromov and Erbaeva 1995).

The molluskan fauna includes several species, such as Carychium, that occur in wooded habitats and wet meadows; Vallonia pulchella and Vertigo pygmaea are most common. Among mammals, there are several species that are typical of meadows with rich forbs, including Microtus arvalis, Microtus ex gr. agrestis, and Microtus (Stenocranius) gregalis. The latter species also likely inhabited steppe-like habitats. Both the mole and the shrew are commonly found in open meadow habitats as well (Gureev 1979, Görner and Hackethal 1988).

Interestingly, the fauna of Mikhailovka-5 includes also typical steppe species among both mollusks and small mammals. Truncatellina cylindrica is a small vertiginid mollusk that, in modern faunas, inhabits dry grasslands and sand dunes. Among small mammals, the ground squirrel Spermophilus ex gr. suslicus, mole rat Spalax ex gr. microphtalmus, and steppe pika Ochotona cf. pusilla are indicative of such conditions. In addition to these species, a single tooth of the yellow steppe lemming Eolagurus indicates the existence of patches of very dry steppe, but such habitats were likely limited in their distribution since their remains make up only $0.2 \%$ of the composition of the entire fauna.

A significant component of the fauna is represented by species associated with bodies of water. Among mollusks, these include Succinea, which lives near water or in periodically flooded areas. Small mammals in such habitats are often represented by the water vole Arvicola, which mainly feeds on the stems of sedges and grasses and inhabits the shorelines of lakes and rivers.

The above-described features of the fossil soils, associated with mollusk and small mammal remains allow a reconstruction of the environmental conditions in the basins of the Seim and Desna rivers during the Mikulino interglacial. These data indicate that during this time the central part of the Russian Plain was dominated by broadleaf forests, which is supported by palynological data indicating the presence of such tree species as beech, linden, oak, and even yew (Grichuk 1983). Open landscapes were mostly represented by meadows. The studied region contained a well-developed network of streams and small rivers; lakes were also present. The watersheds could have included small patches of dry steppes.

Based on the palaeosoil data, the Eastern European Plain during the Mikulino interglacial was dominated by meadows, steppes, and broadleaf forests (Glushankova 2008b). Mikulino corresponds to MIS 5, a stage that is characterized by complex environmental dynamics. In the Desna River basin, MIS 5 included 11 phases of development of vegetation (Bolikhovskaya and Molodkov 2008). The forests were primarily formed by birch (Betula fruticosa), hornbeam (Carpinus betulus), oak (Quercus robur, Q. petraea), linden (Tilia cordata, T. tomentosa), elm (Ulmus laevis), hazelnut 


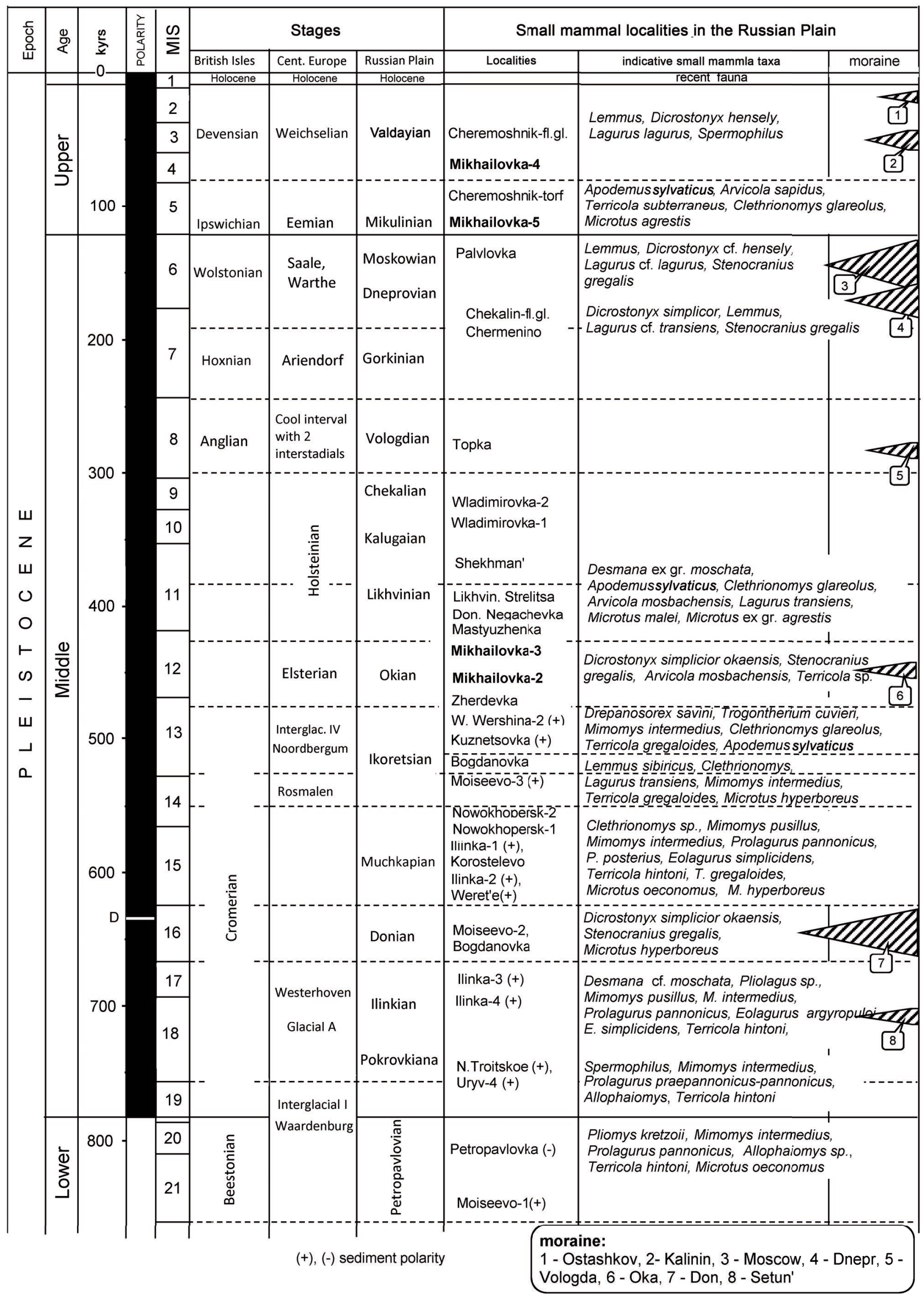

Text-fig. 10. Stratigraphic position of the Mikhailovka faunas and other faunas from the Central Russian Plain. 
(Corylus colurna), and conifers such as fir (Picea abies), pine (Pinus sylvestris), Siberian pine (Pinus sibiricus), and others (Bolikhovskaya and Molodkov 2008). These data correlate well with the findings from the mollusk and small mammal faunas from Mikhailovka-5 (Text-fig. 10).

The stratotype of Mikulinian deposits is located in the southwestern part of the Vitebsk Upland in Belarus. The total thickness of the exposed deposits exceeds $25 \mathrm{~m}$. The upper part of the section is formed by Valdayian glacial deposits that are about $6 \mathrm{~m}$ in thickness. They are underlain by peat and peaty gyttja that is rich in plant fragments and pollen. This layer is close to $2 \mathrm{~m}$ in thickness and belongs to the Mikulinian interglacial (Sanko 1987). The following tree species have been identified based on pollen analysis: Quercus sp., Corylus avellana, Alnus glutinosa, Tilia platyphyllos, T. tomentosa, T. cordata, Carpinus betulus, Betula alba, Picea abies, and Pinus sylvestris. The flora included the following aquatic species: Salvinia natans and Brasenia schreberi (Sanko 1987). Similar flora including Salvinia natans has been described from the Eemian of Netherlands (Zagwijn 1961).

A similar flora was identified from Cheremoshnik (Agadjanian 1972, 1973), another important locality of the Mikulinian interglacial, which is situated $600 \mathrm{~km}$ northwest of the Mikhailovka quarry in the Yaroslavl Oblast near the border that marks the southern extent of the Valdayian glaciation. The total thickness of the section is $11 \mathrm{~m}$. The moraine of the Moskva (= Riss 2) glaciation is located at the bottom of the section overlain by Upper Pleistocene deposits that are $6 \mathrm{~m}$ in thickness. Their lower part is formed by peat and peaty gyttja with wood pieces and is $2 \mathrm{~m}$ thick, while the upper part is formed by fluvio-glacial sands of the Valdayian cold epoch, which yielded a small mammal fauna. More than half of the fossil remains (55.4\%) belong to the collared lemming Dicrostonyx ex gr. gulielmi-henseli (153 specimens), $24.3 \%$ to the Siberian lemming Lemmus cf. sibiricus (67 specimens), and $5.8 \%$ to the narrow-headed vole Microtus (Stenocranius) gregalis (16 specimens); also present in small numbers (3 specimens each) are the steppe lemming Lagurus sp. and ground squirrel Spermophilus sp. (Agadjanian 1972, 1973). Such faunal composition is typical for tundra-steppe of the Valdayian glaciation. According to pollen and radiocarbon data the age is Middle Valday: $46,420 \pm 2,980$ cal. BP (Rusakov et al. 2015). The underlying peat yielded a very different mammalian fauna that included a shrew Sorex sp., water vole Arvicola ex gr. sapidus (17 specimens, $47.2 \%$ ), bank vole Clethrionomys glareolus (6 specimens, $16.7 \%$ ), narrow-headed vole Microtus (Stenocranius) gregalis (3 specimens, $8.3 \%$ ), and Microtus sp. (8 specimens, $22.2 \%$ ) (Agadjanian 1972, 1973). This fauna is of a typical interglacial type and is close in composition to Mikhailovka-5. Based on pollen analysis, pine (Pinus sylvestris), oak (Quercus), and elm (Ulmus laevis), hornbeam (Carpinus), linden (Tilia), and hazelnut (Corylus) were dominant during the formation of the peat. This composition of the tree flora was confirmed by later studies (Rusakov et al. 2015). The same study yielded ${ }^{230} \mathrm{Th} / \mathrm{U}$ (thorium/uranium) dating results of $114 \pm 11.6 / 9.2 \mathrm{ka}$ using the leachate alone $(\mathrm{L} / \mathrm{L})$ and $115 \pm 15.8 / 11.6 \mathrm{ka}$ using the total sample dissolution (TSD), which corresponded to MIS 5e, i.e., to the Mikulinian interglacial (Rusakov et al. 2015).

\section{Conclusions}

The Mikhailovka-5 fauna is characterized by a rich small mammal and terrestrial mollusc fauna that indicates temperate conditions. The fauna is of an interglacial type and lacks any northern species that tolerate colder climate. The faunal composition indicates presence of extensive broadleaf forests with some conifers, significant areas occupied by meadows, and some steppe-like habitats. Such fauna likely existed in climatic conditions similar to the modern ones or even warmer.

The age of the fauna can be determined based on the absence of extinct Middle Pleistocene species of mollusks and small mammals. The dental morphology of small mammal species is similar to the modern ones, but retains some archaic features. There are also some peculiar zoogeographical features, such as a different modern distribution of the faunal elements.

The data on fossil soils, vegetation, mollusks, and small mammals from several localities of the Central Russian Plain, including Mikhailovka-5, allow reconstructions of the environmental conditions of the Mikulinian interglacial for a rather large territory. From these data, we can determine that broadleaf forests with birch and some conifers were widely distributed from the middle Dnieper River to the Don and upper Volga rivers at that time.

Small mammal and mollusk faunas along with morphological, palaeoecological, and stratigraphic evidence indicate that Mikhailovka-5 belongs to the Mikulinian $($ Eemian $=$ Ipswichian $)$ interglacial. Mikulinian faunas are rare in the central Russian Plain and each one presents new important information on the biota and conditions during the last interglacial in eastern Europe.

\section{Acknowledgements}

This work was supported by the Russian Basic Research Foundation, project no. 08-04-00483-a, by the program "Historical Dynamics of Biological Resources and Importance of Their Conservation and Use", and by the program "Origin and Evolution of the Biosphere". The authors would like to thank K. Bogicevic (Belgrade), L. Lebreton (Perpignan), and D. Goggin for the comments on the manuscript.

\section{References}

Agadjanian, A. K. (1972): Verkhnepleystotsenovie Gryzuni Kotloviny Ozera Nero [Upper Pleistocene rodents of the depression of the Nero Lake]. - In: Teriofauna Pleystotsena [Mammal Fauna of the Pleistocene]. MSU Press, Moscow, pp. 275-285. (in Russian)

Agadjanian, A. K. (1973). Kopytnye Lemmingi Pleystotsena [Collared lemmings of the Pleistocene]. - In: Noveyshaya Tektonika i Chelovek, Sbornik 5 [Newest Tectonics and Humans, Collection 5]. MSU Press, Moscow, pp. 320-355. (in Russian)

Agadjanian, A. K. (1983): Eine altertümliche Arvicola (Rodentia, Mammalia) aus dem Mittelpleistozän der Russischen Ebene [An archaic Arvicola (Rodentia, Mamma- 
lia) from the Middle Pleistocene of the Russian Plain]. Schriftenreihe für Geologische Wissenschaften, 19/20: 9-29.

Agadjanian, A. K. (2001): Proiskhozhdenie i evolutsiya: Vodyanaya Polyovka [Origin and evolution: Water vole]. - In: Panteleev, P. S. (ed.), Vodyanaya Polyovka, Obraz Vida [Water vole, Description of the Species], Nauka, Moscow, pp. 22-54. (in Russian)

Agadjanian, A. K. (2009): Melkie Mlekopitayushchie Pliocen-Pleystotsena Russkoy Ravnini [Small Mammals of the Pliocene-Pleistocene of the Russian Plain]. - Palaeonlogical Institute RAS, Moscow, 675 pp. (in Russian)

Agadjanian, A. K., Erbaeva, M. A. (1983): Pozdnekaynozoyskie Gryzuni i zaytzeobraznie territorii SSSR [Late Cenzoic rodents and lagomorphs of USSR]. - Nauka, Moscow, 187 pp. (in Russian)

Agadzhanyan, A. K. (2012): Timing of the Mimomys-Arvicola transition on the Russian Plain. - Quaternary International, 271: 38-49.

https://doi.org/10.1016/j.quaint.2012.03.058

Alexandrova, L. P. (1982): Noviy vid kopytnogo lemminga Dicrostonyx okaensis sp. nov. i ego znachenie dlya opredeleniya vozrasta otlozheniy okskogo oledeneniya likhvinskogo stratotipicheskogo razreza [New species of collared lemming Dicrostonyx okaensis sp. nov. and its importance for the identification of the age of the deposits of the Oka glacial from the Likhvin stratotypic section]. - In: Stratigrafiya i paleogeografiya antropogena [Stratigraphy and Paleogeography of the Anthropogen]. Moscow, Nauka, pp. 17-21. (in Russian)

Alexandrowicz, S. W., Alexandrowicz, W. P. (2010): Molluscs of the Eemian interglacial in Poland. - Annales Societatis Geologorum Poloniae, 80(1): 69-87.

Alexandrowicz, W. P., Łanczont, M., Boguckyj, A. B., Kulesza, P., Dmytruk, R. (2014): Molluscs and ostracods of the Pleistocene loess deposits in the Halych site (Western Ukraine) and their significance for palaeoenvironmental reconstructions. - Quaternary Science Reviews, 105: 162-180.

https://doi.org/10.1016/j.quascirev.2014.10.008

Andrews, P. (1990): Owls, caves, and fossils: predation, preservation, and accumulation of small mammal bones in caves, with an analysis of the Pleistocene cave faunas from Westbury-sub-Mendip, Somerset, UK. - University of Chicago Press, Chicago, $231 \mathrm{pp}$.

Bogićević, K., Nenadić, D., Mihailović, D. (2012): Late Pleistocene voles (Arvicolinae, Rodentia) from the Baranica Cave (Serbia). - Geologia Carpathica, 63(1): 83-94. https://doi.org/10.2478/v10096-012-0006-6

Bolikhovskaya, N. S., Molodkov, A. N. (2008). Periodizatsiya, korrelyatsiya i absolutnyy vozrast tyoplykh i kholodnykh epokh poslednikh 200 tysyach let [Periodization, correlation, and absolute age of warm and cold epochs of the last 200 thousand years]. - In: Bolikhovskaya, N. S., Kaplin, P. A. (eds), Problemi paleogeografii i stratigrafii pleystotsena [Problems of paleogeography and stratigraphy of the Pleistocene]. Geography Faculty of MSU, Moscow, pp. 45-64. (in Russian)

Chaline, J. (1972): Les rongeurs du Pléistocène moyen et supérieur de France. - CNRS, Paris, 410 pp.
Defleur, A. R., Desclaux, E. (2019): Impact of the last interglacial climate change on ecosystems and Neanderthals behavior at Baume Moula-Guercy, Ardèche, France. Journal of Archaeological Science, 104: 114-124. https://doi.org/10.1016/j.jas.2019.01.002

Desclaux, E., Abbassi, M., Marquet, J. C., Chaline, J., van Kolfschoten, T. (2000): Distribution and evolution of Arvicola Lacépède, 1799 (Mammalia, Rodentia) in France and Liguria (Italy) during the Middle and the Upper Pleistocene. - Acta Zoologica Cracoviensia, 43(1-2): 107-125.

Döppes, D., Kempe, S., Rosendahl, W. (2008): Dated Paleontological cave sites of Central Europe from Late Middle Pleistocene to early Upper Pleistocene (OIS 5 to OIS 8). - Quaternary International, 187: 97-104. https://doi.org/10.1016/j.quaint.2007.03.023

Escudé, E., Montuire, S., Desclaux, E. (2008b): Morphological variability within Arvicola cantiana (Arvicolinae, Rodentia) from middle pleistocene to upper pleistocene in France and Liguria (Italy). - Quaternaire, 19: 31-41. https://doi.org/10.4000/quaternaire.1632

Escudé, E., Montuire, S., Desclaux, E., Quéré, J.-P., Renvoisé, E., Jeannet, M. (2008a): Reappraisal of 'chronospecies' and the use of Arvicola (Rodentia, Mammalia) for biochronology. - Journal of Archaeological Science, 35(7): 1867-1879. https://doi.org/10.1016/j.jas.2007.11.018

Fejfar, O., Ložek, V. (1957): Beitrag zum Studium der Fauna des Altpleistozäns von Stránská skála bei Brno. - Věstník Ústředního ústavu geologického, 32: 290-294.

Freudenthal, M., Meijer, T., Meulen, A. J. v. d. (1976): Preliminary report on a field campaign in the continental Pleistocene of Tegelen (The Netherlands). - Scripta geologica, 34: 1-27.

Gerasimov, I. P. (1960): Pochvi Tsentralnoy Evropy i sviyazannie s nimi voprosi fizicheskoy geographii [Soils of Central Europe and Related Issues of Physical Geography]. - Izdatelstvo Akademii Nauk [Academy of Sciences Press], Moscow, 165 pp. (in Russian)

Glushankova, N. I. (2008a): Paleopedogenez i prirodnaya sreda Vostochnoi Evropy v pleystotsene [Palaeopedogenesis and Environmental Conditions in Eastern Europe during the Pleistocene]. - Magenta, Moscow-Smolensk, 348 pp. (in Russian)

Glushankova, N. I. (2008b). Evolutsiya landshaftov vostochno-evropeyskoy ravniny v pleystotsene [Evolution of landscapes of the Eastern European Plain during the Pleistocene]. - In: Bolikhovskaya, N. S., Kaplin, P. A. (eds), Problemi paleogeografii i stratigrafii pleystotsena [Problems of paleogeography and stratigraphy of the Pleistocene]. Geography Faculty of MSU, Moscow, pp. 65-83. (in Russian)

Görner, M., Hackethal, H. (1988): Säugetiere Europas. Neumann Verlag, Leipzig, 372 pp.

Grichuk, V. P. (1983): Istoriya flory i rastitelnosti russkoy ravniny $\mathrm{v}$ pleystotsene [History of the Flora and Vegetation of the Russian Plain during the Pleistocene]. Nauka, Moscow, 183 pp. (in Russian)

Gromov, I. M., Baranova, G. I. (1981): Katalog Mlekopitayushchikh SSSR. Pliotsen-Sovremennost [Catalog of the 
Mammals of USSR. Pliocene through Recent]. - Nauka, Leningrad, 183 pp. (in Russian)

Gromov, I. M., Erbaeva, M. A. (1995): Mlekopitayushchie fauny Rossii i sopredelnykh territoriy. Zaytseobraznye i gryzuny [Mammals of Russia and Adjacent Territories. Lagomorphs and Rodents]. - ZIN RAN, St. Petersburg, 522 pp. (in Russian)

Gromov, I. M., Polyakov, I. Y. (1977): Fauna SSSR. Mlekopitayushchie. Tom V. Vypusk 8. Polevki (Microtinae) [Fauna of the USSR. Mammals. Vol. V, No. 8. Voles (Microtinae)]. - Nauka, Leningrad, 502 pp. (in Russian)

Gureev, A. A. (1979): Fauna SSSR. Mlekopitayushchie. Tom IV. Vypusk 2. Nasekomoyadnye [Fauna of the USSR. Mammals. Volume IV, No. 2. Insectivores]. Nauka, Leningrad, 501 pp. (in Russian)

Heinrich, W. D. (1982): Zur Evolution und Biostratigraphie von Arvicola (Rodentia, Mammalia) im Pleistozän Europas [On evolution and biostratigraphy of Arvicola (Rodentia, Mammalia) in Pleistocene Europe]. - Zeitschrift für Geologische Wissenschaften, 10(6): 693-735.

Heller, F. (1969): Eine Kleinsäugerfauna aus den mittleren Mosbacher Sanden bei Biebrich-Wiesbaden [A small mammal fauna from the middle Mosbacher sands near Biebrich-Wiesbaden]. - Mainzer naturwissenschaftliches Archiv, 8: 25-55.

Jánossy, D. (1976): Die Revision jungmittelpleistozäner Vertebratenfaunen in Ungarn [The revision of the Late Middle Pleistocene vertebrate faunas in Hungary]. Fragmenta Minerologica et Palaeontologica, 7: 29-54.

Jánossy, D. (1985): Pleistocene Vertebrate Faunas of Hungary - Akademiai kiado, Budapest, 208 pp.

Kalinovski, P. F. (1983): Teriofauna pozdnego pleystotsena i golotsena Belorussii [Theriofauna of Late Pleistocene and Holocene of Belarus]. - Nauka i Tekhnika Press, Minsk, 155 pp. (in Russian)

von Koenigswald, W. (1970): Mittelpleistozäne Kleinsäugerfauna aus der Spaltenfüllung Petersbuch bei Eichstätt [Middle Pleistocene small mammal fauna from the fissure-filling of Petersbuch near Eichstätt]. - Mitteilungen der Bayerischen Staatssammlung für Paläontologie und Historische Geologie, 10: 407-432.

von Koenigswald, W. (1973): Veränderungen in der Kleinsäugerfauna von Mitteleuropa zwischen Cromer und Eem (Pleistozän) [Changes in the small mammal fauna of Central Europe between Cromer and Eem (Pleistocene)]. - Eiszeitalter und Gegenwart, 23-24: 159-167. https://doi.org/10.3285/eg.23-24.1.14

van Kolfschoten, T. (2000): The Eemian mammal fauna of central Europe. - Netherlands Journal of Geosciences, 79(2-3): 269-281. https://doi.org/10.1017/S0016774600021752

Likharev, I. M., Rammelmeyer, E. S. (1952): Opredeliteli po faune SSSR [Terrestrial Molluscs of the USSR Fauna]. USSR Academy of Sciences, Moscow, 511 pp. (in Russian)

Limondin-Lozouet, N., Antoine, P. (2001): Palaeoenvironmental changes inferred from malacofaunas in the Lateglacial and early Holocene fluvial sequence at Conty, northern France. - Boreas, 30(2): 148-164. https://doi.org/10.1111/j.1502-3885.2001.tb01219.x

Limondin-Lozouet, N., Antoine, P., Bahain, J. J., Cliquet, D., Coutard, S., Dabkowski, J., Ghaleb, B., Locht, J. L.,
Nicoud, E., Voinchet, P. (2015): North-West European MIS 11 malacological successions: a framework for the timing of Acheulean settlements. - Journal of Quaternary Science, 30(7): 702-712.

https://doi.org/10.1111/j.1502-3885.2001.tb01219.x

López-García, J. M., Berto, C., Colamussi, V., Valle, C. D., Vetro, D. L., Luzi, E., Malavasi, G., Martini, F., Sala, B. (2014): Palaeoenvironmental and palaeoclimatic reconstruction of the latest Pleistocene-Holocene sequence from Grotta del Romito (Calabria, southern Italy) using the small-mammal assemblages. - Palaeogeography, Palaeoclimatology, Palaeoecology, 409: 169-179. https://doi.org/10.1016/j.palaeo.2014.05.017

López-García, J. M., Blain, H. A., Cuenca-Bescós, G., Alonso, C., Alonso, S., Vaquero, M. (2011): Small vertebrates (Amphibia, Squamata, Mammalia) from the late Pleistocene-Holocene of the Valdavara-1 cave (Galicia, northwestern Spain). - Geobios, 44: 253-269. https://doi.org/10.1016/j.geobios.2010.10.001

Ložek, V. (1964): Quartärmollusken der Tschechoslowakei. - Rozpravy Ústředního ústavu geologického, 31: $1-374 \mathrm{pp}$.

Lyell, C. (1872): Principles of Geology. 2 vols (11 ${ }^{\text {th }}$ ed.). D. Appleton and Company, New York, $\mathrm{xx}+671$ pp., xviii +652 pp.

Markova, A. K. (1982): Pleystotsenovye gryzuny Russkoy Ravniny [Pleistocene Rodents of the Russian Plain]. Nauka, Moscow, 184 pp. (in Russian)

Markova, A. K. (1986): Morfologicheskie osobennosti zubov Arvicola, Lagurus, Eolagurus i Microtus (Rodentia, Cricetidae) iz Mikulinskikh mestonakhozhdeniy Russkoy Ravnini [The morphological features of teeth Arvicola, Lagurus, Eolagurus and Microtus (Rodentia, Cricetidae) from the Mikulino localities of Russian Plain]. - Trudy Zoologicheskogo Instituta Akademii Nauk SSSR, 149: 74-97. (in Russian)

Markova, A. K. (2000): The Mikulino (= Eemian) mammal faunas of the Russian Plain and Crimea. - Netherlands Journal of Geosciences, 79(2-3): 293-301. https://doi.org/10.1017/S0016774600021776

Montuire, S., Desclaux, E. (1997): Palaeoecological analysis of mammalian faunas and environmental evolution in the South of France during the Pleistocene. - Boreas, 26: 355-365. https://doi.org/10.1111/j.1502-3885.1997.tb00861.x

Nehring, A. (1890): Über Tundren und Steppen der Jetztund Vorzeit [About Tundra and Steppes of the Present and Past]. - Ferd. Dümmlers Verlagsbuchhandlung, Berlin, 146 pp.

Osipova, E., Danukalova, G., Marković, S. B. (2013): Malacological characteristics of the Middle to Upper Pleistocene transitional interval (MIS 7-5) observed in the Batajnica locality (Serbia). - Quaternary International, 292: 86-100. https://doi.org/10.1016/j.quaint.2012.10.042

Radulesco, C., Samson, P. (1977): Arvicola (Rodentia, Mammalia) dans le Pleistocene moyen de Roumanie. Travaux de l'Institut de Spéologie "Émile Racovitza", 16: $151-162$.

Reichstein, H. (1963): Beitrag zur systematischen Gliederung des Genus Arvicola Lacepede, 1799. - Zeitschrift 
für zoologische Systematik und Evolutionsforschung, 1(1-2): 155-204. https://doi.org/10.1111/j.1439-0469.1963.tb01627.x

Rousseau, D.-D., Puisségur, J.-J. (1999): Climatic interpretation of terrestrial malacofaunas of the last interglacial in southeastern France. - Palaeogeography, Palaeoclimatology, Palaeoecology, 151(4): 321-336. https://doi.org/10.1016/S0031-0182(99)00021-8

Rusakov, A., Nikonov, A., Savelieva, L., Simakova, A., Sedov, S., Maksimov, F., Kuznetsov, V., Savenko, V., Starikova, A., Korkka, M., Titova, D. (2015): Landscape evolution in the periglacial zone of Eastern Europe since MIS5: Proxies from paleosols and sediments of the Cheremoshnik key site (Upper Volga, Russia). - Quaternary International, 365: 26-41. https://doi.org/10.1016/j.quaint.2014.09.029

Sanko, A. F. (1987): Neopleystotsen severo-vostochnoy Belorussii i smezhnikh Rayonov [Neopleistocene of northeastern Belarus and neighboring regions]. - Nauka i Tekhnika, Minsk, 178 pp. (in Russian)

Sanko, A. F., Motuzko, A. N. (1991): Molluski i mlekopitayushchie iz izvestkovyh tufov Borisovoy Gory na Zapadnoy Dvine [Molluscs and mammals from calcareous tuffs of Borisova Gora on Zapadnaya Dvina]. - Doklady Akademii nauk Belarusskoy Socialisticheskoy Respubliki, Geologia, 35: 1004-1008. (in Russian)

Schreve, D. C. (2001): Differentiation of the British late Middle Pleistocene interglacials: the evidence from mammalian biostratigraphy. - Quaternary Science Reviews, 20(16): 1693-1705.

https://doi.org/10.1016/S0277-3791(01)00033-6

Shileyko, A. A. (1984): Nazemnye Molluski Podotryada Pupillina Fauny SSSR [Terrestrial mollusks of the suborder Pupillina of the USSR fauna] - Nauka, St. Petersburg, 399 pp. (in Russian)

Socha, P. (2014): Rodent palaeofaunas from Biśnik Cave (Kraków-Częstochowa Upland, Poland): Palaeoecological, palaeoclimatic and biostratigraphic reconstruction. - Quaternary International, 326-327: 64-81. https://doi.org/10.1016/j.quaint.2013.12.027

Sutcliffe, A. J., Kowalski, K. (1976): Pleistocene rodents of the British Isles. - Bulletin of the British Museum (Natural History), 27(2): 31-147.

Tesakov, A. (1998): Voles of the Tegelen fauna. - Mededelingen Nederlands Instituut voor Toegepaste Geowetenschappen TNO, 60: 71-134.

Turner, C. (2000): The Eemian interglacial in the North European plain and adjacent areas. - Netherlands Journal of Geosciences, 79(2-3): 217-231. https://doi.org/10.1017/S0016774600023660

Welter-Schultes, F. (2012): European Non-Marine Molluscs: A Guide for Species Identification - Planet Poster Editions, Gottingen, 760 pp.

Zagwijn, W. (1961): Vegetation, climate and radiocarbon datings in the late Pleistocene of the Netherlands, Part I: Eemian and Early Weichselian. - Mededeelingen van de Geologische Stichting, Nieuwe Serie, 14: 15-45.

\section{Explanations to the plate}

\section{PLATE 1}

Key mollusk species from Mikhailovka-5

1. Acme (Platyla) polita (HARTMAnN, 1840); a - apertural view, $\mathrm{b}$ - antiapertural view.

2. Vertigo (Isthmia) pygmaea (DRAPARNAUd, 1801); $\mathrm{a}-$ apertural view, $\mathrm{b}$ - antiapertural view.

3. Vertigo (Vertigo) pusilla Müller, 1774; a - apertural view, $\mathrm{b}$ - antiapertural view.

4. Vertilla angustior (JEFFREYs, 1830); a - apertural view, $\mathrm{b}$ - antiapertural view.

5. Vertigo (Vertigo) antivertigo (DRAPARNAUD, 1801); apertural view.

6. Vertigo (Vertigo) substriata (JEFFREYs, 1830); $\mathrm{a}$ - apertural view, b - antiapertural view.

7. Truncatellina cylindrica (FÉRUSSAC, 1807); a - apertural view, $\mathrm{b}$ - antiapertural view.

8. Punctum pygmaeum (Draparnaud, 1801); a - apical view, $\mathrm{b}$ - umbilical view.

9. Acanthinula aculeata (MÜLLER, 1774); apertural view.

10. Macrogastra plicatula (DRAPARNAUd, 1801); $\mathrm{a}$ - clausilium, $\mathrm{b}$ - apertural view, $\mathrm{c}-$ antiapertural view.

11. Ruthenica filograna (ROSSMÄSSLER, 1836); a - apertural view, $\mathrm{b}$ - antiapertural view.

Scale bar equals $5 \mathrm{~mm}$ for Figs $1-10 \mathrm{a}$ and $10 \mathrm{~mm}$ for Figs $10 \mathrm{~b}-\mathrm{c}$ and 11. 
PLATE 1

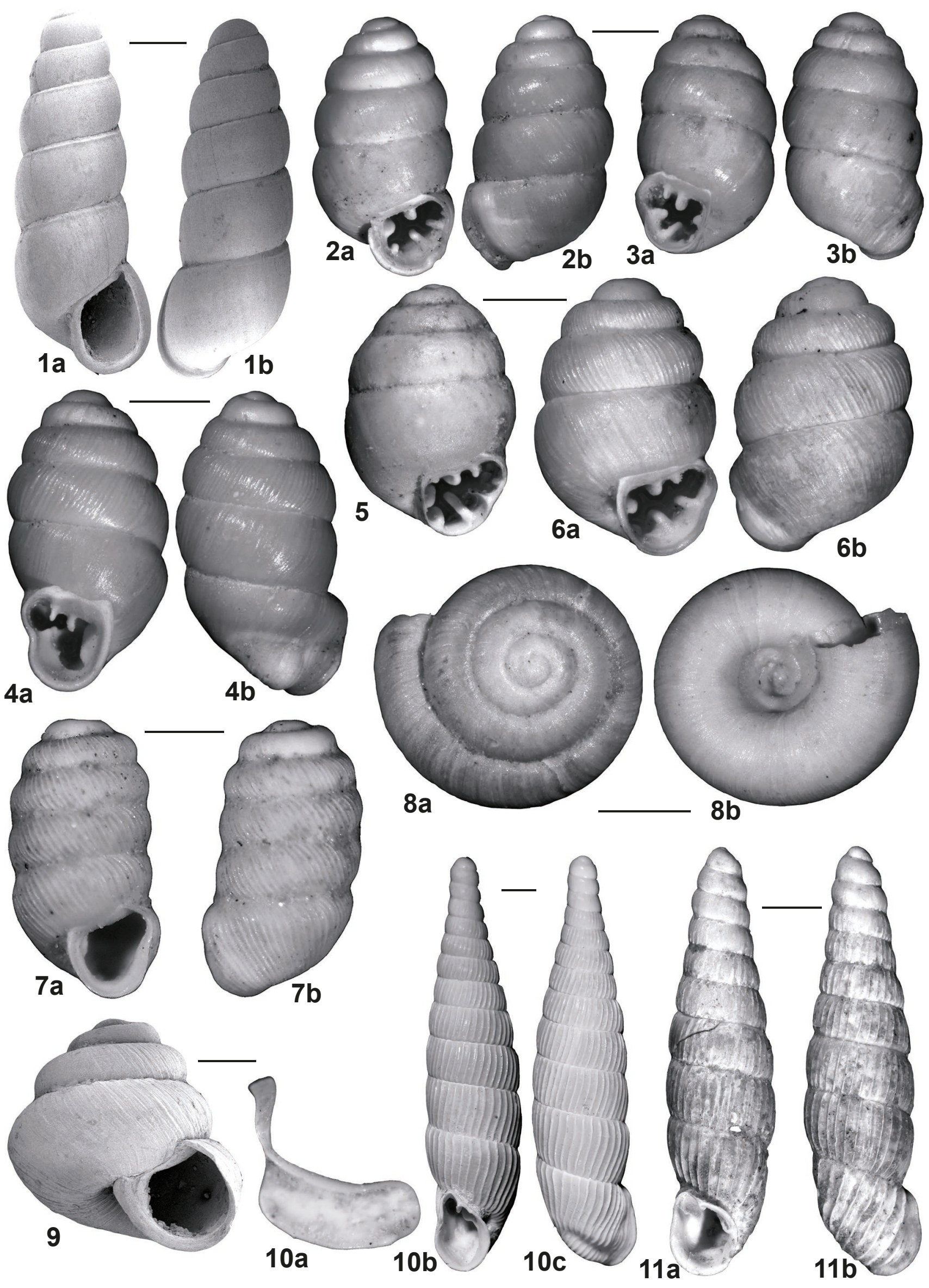

